\title{
The Role of Non-Phagocytic Cells in Mycobacterial Infections
}

\author{
B.E. Garcia-Perez, N.S. Castrejon-Jimenez and J. Luna-Herrera \\ Departamento de Inmunología, Escuela Nacional de Ciencias Biológicas, IPN \\ México, D.F., \\ México
}

\section{Introduction}

Tuberculosis is one of the infectious diseases with great impact in the world. It affects mainly to young adults in the productive stage of the life and most of the deaths due to this disease occur in developing countries. All the cities are affected, but $85 \%$ of the cases occur in Africa (30\%) and Asia (55\%). In 2009, the WHO reported 9.4 million new cases, 14 million prevalent cases and 1.7 million deaths; in addition, there is an estimate that one third part of the world-wide population lodges the latent infection. These data place tuberculosis like the third cause of death at world-wide level, after HIV/ AIDS and cardiac diseases (WHO, 2010).

Mycobacterium tuberculosis, the causal agent of tuberculosis, is a slow growth, acid-fast resistant bacillus, has a complex cellular wall constituted by complex lipids and carbohydrates. It is a facultative intracellular pathogen able to infect and to survive within the hosts cells. M. tuberculosis has developed numerous strategies to evade the immune response, so it is considered one of the most successful pathogens.

M. tuberculosis reach the human body through small drops expel by individuals with active disease. Once within the respiratory tract $M$. tuberculosis reaches the alveolar space and bounds to specific receptors of alveolar macrophages, dendritic cells and monocytes. For years the paradigm has been that alveolar macrophages are the main cells responsible of endocytosis, recognition and handling of M. tuberculosis. However, actual evidence demonstrates that non-phagocytic cells interact, harbour and respond to M. tuberculosis. In this work we will present and discuss some of the most relevant information on the interaction of non-phagocytic cells-M. tuberculosis, but first a brief revision of the main receptors described on macrophages and their role in the recognition of $M$. tuberculosis will be presented.

\section{Mycobacterium tuberculosis interaction with macrophages}

The lung is a highly susceptible organ for the invasion and establishment of microorganisms that are transmitted by aerosols. To guarantee control and elimination of those microorganisms that skip physical and chemical barriers of respiratory system, the lung requires activation coordinated and regulated by cells from the immune system located at 
the bronchoalveolar space, like macrophages, lymphocytes, mast cells, neutrophils, etc. Macrophages play an important role in the innate and adaptive immune response towards pathogenic microorganisms, and are implied in their recognition and phagocytosis, in their processing and antigen presentation, in the antimicrobial metabolite production and in the production of cytokines that contribute to recruitment and activation of other cellular lineages that amplify and control the immunological response. Due to their anatomical location in the interface of the alveolar space, the alveolar macrophages are the first line against environmental particles or microorganisms that reach the lung (Schneberger et al., 2011). Alveolar macrophages express several immune receptors like the FC- $\gamma$ receptors and complement receptors (CR1, CR3 and CR4), and high levels of molecules know as "Pattern recognition receptors" or PRRs, like mannose receptor (MR), Dectin-1 ( $\beta$-glucan receptor), scavengers receptors, Toll-like receptors (TLRs) and NOD-like receptors (NLRs) (Fels \& Cohn, 1986; Means et al., 2001; Palecanda \& Kobzik, 2001; Srivastava et al., 2007; Stephenson \& Shepherd, 1987; Taylor et al., 2002). Although alveolar macrophages have been attributed with pro-inflammatory functions (Schneberger et al., 2011), numerous reports indicate that alveolar macrophages rather exhibit an anti-inflammatory phenotype, known as "alternative activation", which includes an altered cytokine response enriched of IL-10 and TGF- $\beta$ (Takabayshi et al., 2006), a reduced production of oxygen metabolites in response to stimuli and a decreased antimicrobial activity (Gordon, 2003).

Initial encounter of phagocytic cells with mycobacteria is a complex event and relays on several factors including those of the host and those of the bacteria. It seems that $M$. tuberculosis interaction do not depend on a single ligand-receptor bound (Schäfer et al., 2009). Apparently, during interaction, several receptors maybe involved each one with different roles. Final result of cell receptors-mycobacteria ligands engagement will be dependent of the type and number of cell receptors expressed by each cell lineage, and the intracellular signaling response triggered during those interactions. Next, the main receptors involved in the macrophage-M. tuberculosis recognition will be discussed.

\subsection{C-type lectins}

C-type lectins play an important role in M. tuberculosis recognition and in the inflammatory response. C-type lectins include a big family of proteins that bound carbohydrates (Anderson et al., 2008) and can be classified in soluble lectins and lectins associated to the cellular membrane (transmembrane lectins). The relevant soluble C-type lectins for mycobacterial infection are proteins $\mathrm{A}$ and $\mathrm{D}$ of the pulmonary surfactant (SP-A and SP-D). SP-A and SP-D are secreted into the alveolar space mainly by the type II pneumocytes. SP-A promotes $M$. tuberculosis phagocytosis through direct interaction of SP-A with the macrophages (Gaynor et al, 1995), which then over-express mannose-receptor (Beharka et al., 2002). In contrast, SP-D boosts mycobacteria agglutination and decrease mycobacteria phagocytosis by reducing mycobacterium recognition by mannose receptor (Ferguson et al., 1999; Torreles et al., 2008).

The most important transmembrane C-type lectins for $M$. tuberculosis recognition are mannose-receptor (MR), DC-SIGN and Dectin-1. M. tuberculosis recognition by human macrophages is primarily carried out through MR and it is associated to an antiinflammatory response (Chieppa et al., 2003; Schlesinger, 1993). MR is a C-type lectin expressed by tissue macrophages, alveolar macrophages and dendritic cells, but not by 
monocytes (Stahl \& Ezekowitz, 1998). MR is a PRR that recognizes mannose-capped lipoarabinomannan (ManLAM), the most abundant mycobacterial lipoglycan (Schlesinger et al., 1994). M. tuberculosis interaction to MR depends of length, exposure and abundance of the ManLAMs on mycobacterium surface, in addition mycobacteria recognition by MR are limited to virulent species of $M$. tuberculosis complex (Schlesinger, 1993). The bound of $M$. tuberculosis to MR through ManLAM triggers an anti-inflammatory signaling pathway interfering with IL-12 production induced by lipopolysaccharide (Nigou et al., 2001), which suggests that this interaction hamper macrophage response towards $M$. tuberculosis promoting then mycobacterial infection (Jo, 2008). In addition, it has been demonstrated that engagement of MR by ManLAM during phagocytosis is crucial to delay phagosome maturation and for inhibition of phago-lysosome fusion (Astarie-Dequeker et al., 1999; Kang et al., 2005), initiating then the building of a secure niche for M. tuberculosis survival (Kang et al., 2005).

DC-SIGN (Dendritic cell-specific intercellular adhesion molecule-3 grabbing non-integrin or CD 209) is a transmembrane C-type lectin expressed mainly by dendritic cells, but is also expressed by some macrophage subpopulations (Soilleux et al., 2002); 70\% of alveolar macrophages from individuals with tuberculosis express this receptor (Tailleux et al., 2005). DC-SIGN presents a carbohydrate recognition domain (CRD) that recognizes structures with high mannose content and blood group antigens containing fucose (Appelmelk et al., 2003; Mitchell et al., 2001). In vitro studies showed that in dendritic cells, DC-SIGN is the main phagocytic receptor for M. tuberculosis (Tailleux et al., 2003). Activation trough DCSIGN in the mycobacterial infection depends on agonists for this receptor expressed by each mycobacteria strain. Seven mycobacterial molecules recognized by DC-SIGN include lipomannan, mannose capped arabinomannan, two mannoside glycoproteins (Pitarque et al., 2005), phosphatide-inositide mannosides (Torrelles et al., 2006), ManLAM (Geijtenbeek et al., 2003) and a-glucan (Geurtsen et al., 2009). DC-SIGN can differentiate mycobacterial species through selective recognition of these mycobacterial molecules, especially ManLAM, present in $M$. tuberculosis but absent in non-tuberculosis mycobacteria like M. smegmatis, $M$. chelonae and M. fortuitum. Intracellular fate of M. tuberculosis inside dendritic cells differs from that into macrophages, whereas in macrophages $M$. tuberculosis may survive and replicate, into the hostile environment developed by dendritic cells $M$. tuberculosis growth is inhibited (Herrmann \& Lagrange, 2005). It has been suggested that this difference is due to uptake features and intracellular trafficking of $M$. tuberculosis into each cell type and to the balance and relative activity of MR and DC-SIGN on each cell surface. Macrophages express high levels of MR whereas dendritic cells express high DC-SIGN activity; it has been speculated that this difference explains why macrophages are the main intracellular niche for M. tuberculosis (Kang et al., 2005).

Dectin-1 is a type II transmembrane receptor, which contains a single extracellular CRD and a tyrosine-based activation motif (ITAM) involved in cellular activation (Herre et al., 2004a; McGreal et al., 2005). This receptor is expressed predominantly by myeloid cells like macrophages, dendritic cells, neutrophils, and a sub-type of $\mathrm{T}$ cell; its expression is influenced by cytokines and several microbial products (Taylor et al., 2002; Willment et al., 2003). Dectin- 1 acts as a PRR and recognizes particulate and soluble $\beta$-glucans (Herre et al., 2004a). Activation of Dectin-1 induces numerous cellular responses, like pathogens uptake, production of reactive oxygen species, and cytokines and chemokines production, making 
Dectin-1 a link between the innate and the adaptive immune response (Brown et al., 2003; Taylor et al., 2007). Most of the studies have been focused to establish the role of Dectin- 1 on fungi infections; however, the importance of this receptor in bacterial infections is less known. Recently, some investigators have suggested that Dectin-1 has an important role in the proinflammatory response against mycobacterial infections (Rothfuchs et al., 2007; Yadav \& Schorey, 2006). It has been reported that TNF-a production by macrophages infected with virulent strains of M. avium and M. tuberculosis is Dectin-1 dependent, the opposite occurred in macrophage infections with avirulent or attenuated mycobacterial strains like M. smegmatis, M. phlei or M. bovis BCG; the minimal proinflammatory response elicited by macrophages infected with virulent mycobacteria has been attributed to Dectin-1 engagement (Yadav \& Schorey, 2006). It has been demonstrated that during fungal pathogens recognition by macrophages, TLR2 and Dectin-1 have a synergic effect (Rothfuchs et al., 2007; Shin et al., 2008; Yadav \& Schorey, 2006), a similar situation has not been reported for mycobacterial infections. On the contrary, a recent study showed that $M$. tuberculosis recognition by Dectin-1 triggers a Th1 and Th17 immune response against mycobacteria and is independent of TLR2 recognition (van de Veerdonk et al., 2010). The mycobacterial component recognized by Dectin- 1 is unknown, the presence of $\beta$-glucans in the mycobacteria has not been reported yet, some hypotheses suggest that a-glucans presents in M. tuberculosis and BCG could be the molecules recognized by this receptor (Dinadayala et al., 2004; Lemassu \& Daffe, 1994).

Other C-type lectin receptor involved in mycobacterial PAMPs recognition, include Mincle (macrophage inducible C-type lectin), which is expressed by macrophages expose to inflammatory stimuli like LPS, IL-6, etc. (Matsumoto et al., 1999). Ishikawa and collaborators demonstrated that Mincle bounds the mycobacterial glycolipid Trehalose-6-6'-dimycolate (TDM) also known as cord factor (Ishikawa et al., 2009), which is one of the most studied mycobacterial constituent with immunostimulatory activity.

Complement receptor 3 (CR3), also known as CD11b/CD18 or Mac-1, is a cell membrane heterodimeric receptor, belonging to the integrin superfamily, and in spite of this presents a lectin domain that interacts with M. tuberculosis components (Schäfer et al., 2009). Neutrophils, monocytes, natural killer cells and alveolar macrophages express this receptor, although it has been reported opsonic bound of M. tuberculosis to alveolar macrophages is inefficient because these cells express low amounts of CR3 (Stokes et al., 1998). It has been described that the CR3 is the main complement receptor in the opsonic mycobacteria phagocytosis, $80 \%$ of the opsonized mycobacteria is uptake trough this receptor. Interestingly, CR3 can bind a wide variety of ligands and since it presents multiple bounding sites, CR3 may promote opsonic and non-opsonic M. tuberculosis endocytosis (Velasco-Velazquez et al., 2003). Most of the evidence indicates that CR3 is responsible of mycobacterial bounding and internalization into the macrophage, however, lack of CR3 expression does not have a significant effect on the production of reactive oxygen species or nitric oxide by macrophages (Rooyakkers \& Stokes, 2005; Velasco-Velazquez et al., 2003).

\subsection{Scavenger receptors}

The cell membrane glycoprotein CD36 (scavenger receptor class B) is found in macrophages, dendritic cells, endothelial cells and other cell types (Murphy et al., 2005). CD36 has been implied in several cellular functions like fatty acid transport, angiogenesis regulation, 
inflammation and as PRR participates in the innate immune response against several pathogens including mycobacteria (Febbraio et al., 2001). The role of CD36 in protection against mycobacteria is controversial, recently Hawkes and collaborators (2010) demonstrated that CD36-deficiency confers resistance to mycobacterial infection; macrophages from CD36-/- mice allowed a reduction in the mycobacteria intracellular survival, but the mechanisms responsible of mycobacterial growth containment were not clear. They suggest that the better response of the knock-out mice could be due to the impairment of mycobacterial immune evasion strategies that take advantage of CD36. Detailed structural studies of the mycobacterial cell wall lipomannans have demonstrated that diacylated lipomannans inhibit LPS-induced inflammation by murine macrophages (Doz et al., 2007). Intriguingly, CD36 is a sensor of diacylglycerides (Hoebe et al., 2005) and may be the host receptor through which diacylated mycobacterial lipomannans suppress macrophage function. Another possible explanation is that through its association with the TLR2/ 6 heterodimer, CD36 may participate in immune-suppressor responses dependent of TLR2 as was reported by Noss and collaborators (2001). The family of scavenger receptors also includes macrophage receptor with collagen structure (MARCO) and scavenger receptors class A type I and II (SR-A). They are expressed in alveolar macrophages and dendritic cells (Areschoug \& Gordon, 2009; Pearson, 1996). MARCO and SR-A bound acetylated-low density lipoproteins and bacteria; they promote inhaled particles and bacteria uptake (Arredouani et al., 2005; Palecanda et al., 1999). A recent report describe that macrophages expressing MARCO and bounding TDM respond producing proinflammatory cytokines, but this response required the concomitant participation of TLR2 and CD14 (Bowdish et al., 2009). With respect to SR-A, this receptor can also bound TDM, nevertheless, this recognition diminishes TNF-a/MIP-1-a production by activated macrophages, suggesting that SR-A have an important role in the suppression of the excessive inflammatory response presented during mycobacterial infection (Ozeki et al., 2006). Recent evidence suggest that scavenger receptors along with C-type lectins, cooperate to maintain controlled the immune response established in vivo against the mycobacterial infection (Court et al., 2010).

\subsection{Toll like-receptors and NOD2}

Toll like-receptors (TLRs) are not directly implied in microbial uptake; however, bacterial recognition by TLRs triggers an innate and adaptive immune response through the activation of monocytes, macrophages and dendritic cells. TLRs engagement by $M$. tuberculosis or its components is one of the first events in the M. tuberculosis-host cell interactions, resulting in activation of signaling cascades that culminates in production of proinflammatory responses. TLRs are expressed on immune cells like macrophages, dendritic cells, B lymphocytes, some types of $\mathrm{T}$ cells and some non-immune cells also express TLRs, like endothelial, fibroblasts and epithelial cells (Akira et al., 2006). The TLRs involved in M. tuberculosis recognition are TLR2, TLR4, TLR9 and TLR1/TLR6 that forms a heterodimer with TLR2 (Jo, 2008; Jo et al., 2007; Ryffel et al., 2005). Several studies have reported a number of mycobacterial lipids and proteins implied in TLR recognition and signaling, Jo and colleagues in 2007 presented an excellent review of these findings. Most of the studies oriented to explain the role of TLRs in mycobacterial infection, have been made in TLR knock-out mice, in this way, the protective role of TLR2 and in lesser extend of TLR4 was demonstrated, especially in the acute phase of the infection (Tjärnlund et al., 
2006). In addition, the finding that macrophages from mice TLR2-/- are not able to control mycobacterial growth, correlates with a reduction in TNF-a production by this cells (Tjärnlund et al., 2006). TNF-a is clue cytokine to contain mycobacterial infection (Roach et al., 2002); TLR2 engagement triggers an excellent TNF-a production, making this receptor an important element against mycobacterial infection. The role of TLR4 in the protection against $M$. tuberculosis infection is not absolutely accepted, some evidences demonstrate that TLR4 plays a protective role in the defense against pulmonary tuberculosis, since mice expressing a non-functional TLR4 had higher mortality and higher bacillary loads in the lungs (Branger et al., 2004). However, other reports demonstrated that mice with deficient TLR4 receptors are equally susceptible to $M$. tuberculosis or M. avium infections that the wild type mice (Feng et al., 2003; Reiling et al., 2002). Jo and coworkers suggested that these differences may depend of the signaling route involved, whereas the molecules that engage TLR2 will involve only MyD88 (myeloid differentiation primary response protein 88 ), those molecules that engage TLR4 may generate signals MyD88 dependent and independent (Jo et al., 2007). Another TLR with an important role in the antimycobacterial response is TLR9; mice TLR9-deficient were more susceptible to $M$. tuberculosis and mice with a combined TLR2 and TLR9 deficiency, were much more susceptibility to the infection (Bafica et al., 2005), pointing towards the need of the combined presence of these receptors for a better protection against tuberculosis. Nevertheless, other studies demonstrated that none of these TLRs (2, 4 and 9) are required to induce an adaptive immune response cellular, but the single MyD88 deficiency favored the unrestricted growth of $M$. tuberculosis, indicating the crucial role of this molecule for the generation of efficient effectors mechanisms by the macrophage (Hölscher et al., 2008). The role of other TLRs like TLR1 or TLR6 is not clear yet, it has been reported that mice TLR6-deficient are resistant to M. tuberculosis infection at high doses (Sugawara et al., 2003) and some clinical studies looking for associations between the mycobacterial infection and polymorphisms of a single nucleotide (SNPs) in the TLRs genes demonstrated that TLR1 SNP 1602S regulates the innate immune response towards the triacyl-lipopeptide and towards mycobacterium extracts (Hawn et al., 2007).

TLRs and C-type lectin receptors are molecules present on the plasma or endosomal membranes that recognize microbial components, whereas NOD (nucleotide binding oligomerization domain) receptors are expressed in the cytoplasm. Several evidences indicate that NODs family has an important role in the recognition of intracellular bacteria like M. tuberculosis (Takeda \& Akira, 2005). NOD2 is a member of the Nod like receptors (NLRs) that recognizes muramyl-dipeptide (MDP), a key component of the peptidoglycan of Gram negative and Gram positive bacteria; on the contrary NOD1 recognizes only peptidoglycan from Gram negative bacteria. The intracellular location of NOD2 and $M$. tuberculosis, and the high content of peptidoglycan in mycobacterium cell wall allowed to suggest NOD2 as candidate for mycobacterium recognition. A recent study reported that NOD2 deficient mice (-/-) had high bacterial load in their lungs after M. tuberculosis infection, and a deficient cytokine production, suggesting that NOD2 participates in the resistance against mycobacterial infection, favoring the innate and adaptive immunity (Divangahi et al., 2008). Ferwerda and coworkers reported that NOD2 along with TLR2 represent a non-redundant system for $M$. tuberculosis recognition, and demonstrated that mycobacterial ligands for TLR2 and NOD2 synergize for proinflammatory cytokine production (Ferwerda et al., 2005). 
Numerous are the receptors expressed by the macrophage and numerous are the receptors described for $M$. tuberculosis recognition (Table 1), nevertheless is obvious that $M$. tuberculosis recognition and internalization will not depend solely of a single receptor-ligand interaction. Additionally, mycobacterium surface displays many molecules, which may bound diverse receptors and hence activate different signaling routes. For these reasons during mycobacteria-macrophage interaction the possibility of multiple receptor-ligands interaction is high, so the first question arose, which of the multiple interactions will be the predominant? Then, which of the multiple signaling pathways activated in the cell will be executed? Presented in this way it looks like a chaotic scenario, so it is probable that the ultimate response, will be the final result of the multiple individual responses, for instance if during the interaction, many TLRs are engaged, a robust intracellular signaling response leading towards an inflammatory response will be building up, but if at the same time some lectin C-type receptors like mannose-receptors are engaged, favoring an anti-inflammatory response, then the final response will be a weaker inflammatory response. On the other side, the mycobacteria will have an active role for unbalance the host-response for their benefit, for instance, virulent mycobacteria over-express and expose for their easy recognition, those ligands with anti-inflammatory activity like ManLAM (recognized mainly by MR), whereas less virulent mycobacteria expose phosphoinositide-capped lipoarabinomannans that are considered as proinflammatory molecules. In summary, the studies briefly described here, suggest that the final outcome of the intracellular mycobacteria (survival or elimination) into the phagocytic cell, will be depending in much by the first encounter with the host cell, the mycobacterial components recognized in the encounter and the type and amount of receptors involved in the recognition.

\begin{tabular}{|c|c|c|c|c|}
\hline \multicolumn{3}{|c|}{ Receptor } & Mycobacterlal components & Reference \\
\hline \multirow{11}{*}{ C-Type lectins } & & SP-A & LAM, ManLAM & Sidobre, et al., 2000 \\
\hline & Soluble lectins & SP-D & LAM & Ferguson, et al.,1999 \\
\hline & \multirow{9}{*}{$\begin{array}{l}\text { Lectins associated to } \\
\text { the cellular membrane }\end{array}$} & Mannose receptor & ManLAM & Schlesinger, et al., 1994 \\
\hline & & Dectin-1 & Particulate and soluble $\beta$-glucan & Herre, et al., 2004 \\
\hline & & & Man LAM & Geijtenbeek, et al., 2003 \\
\hline & & & Lipomannan & Pitarque, et al., 2005 \\
\hline & & DC-SIGN & Mannose-capped arabinomannana & Pitarque, et al., 2005 \\
\hline & & & Two mannositide & Pitarque, et al., 2005 \\
\hline & & & Phosphatide-inositide mannosides & Torrelles, et al., 2006 \\
\hline & & & $\alpha$-glucan & Geurtsen, et al., 2009 \\
\hline & & Mincle & Glycolipid Trehalose-6-6'-dimycolate & Ishikawa, et al., 2009 \\
\hline \multirow{2}{*}{\multicolumn{2}{|c|}{ Complement }} & CR3 & LAM & Thorson, et al., 2001 \\
\hline & & & $\mathrm{Ag} 85 \mathrm{C}$ & Hetland and Wiker, 1994 \\
\hline \multicolumn{2}{|l|}{ Scavenger } & SR-B & Sulfolipids & Ernst JD, 1998 \\
\hline \multirow{6}{*}{\multicolumn{2}{|c|}{ TLR }} & & $\begin{array}{l}19 \mathrm{kDa}, 27 \mathrm{kDa} \text {, lipoprotein } \\
\text { Lipomannan }\end{array}$ & $\begin{array}{l}\text { Brightbill, et al., 1999, Hovav, et al., } 2004 \\
\text { Vignal, et al., } 2003\end{array}$ \\
\hline & & TLR2 & Phosphatidyl-myo-inositol mannoside & Gilleron, et al., 2003 \\
\hline & & & LprA y LprG lipoprotein & $\begin{array}{l}\text { Pecora, et al., } 2006 \\
\text { Gehring, et al., } 2004\end{array}$ \\
\hline & & TLR2, TLR4 & HSP70 & Bulut, et al., 2005 \\
\hline & & TLR4 & HSP65 & Bulut, et al., 2005 \\
\hline & & TLR1, TLR6 y TLR2 & Soluble tuberculosis factor & Bulut, et al., 2001 \\
\hline \multicolumn{2}{|l|}{ NOD } & NOD2 & Muramyl dipeptide & Saiga, et al., 2011 \\
\hline
\end{tabular}

Table 1. Phagocytic cell receptors and molecules involved in M. tuberculosis recognition. 


\section{Mycobacterium tuberculosis interaction with non-phagocytic cells}

As it was stated earlier, interaction between intracellular pathogens and their host cells is a highly complex process, conformed by mechanisms that during bacterial and host cell evolution have guaranteed their nowadays survival. For the host cell, diverse strategies are displayed to contain the infection. Most of the strategies elicited by phagocytic cells are known, but bacterial containment does not rely only on phagocytic cells, other cell types participate also, these cells in conjunction are known as non-phagocytic cells. From the host cells side, phagocytic or non-phagocytic cells employ diverse mechanisms for bacterial containment, beginning with bacterial uptake up to the establishment of an adequate cellular activation state, which includes the display of effective antimicrobial mechanisms, apoptosis induction, autophagy or bacterial Ag presentation for recognition and death induction by activated cytotoxic lymphocytes, among others. From the pathogen perspective, these have developed numerous strategies to overcome the defense mechanisms elicited by the host cells. Actual evidence of the ability of intracellular pathogens to induce their entrance into non-phagocytic cells, have supported the hypothesis that these cells may be reservoirs of intracellular pathogens favoring their survival and persistence.

\subsection{Epithelial cells infection by M. tuberculosis}

Among the cells that comprise the pulmonary epithelium, alveolar epithelial cells type II are the non-phagocytic cell most studied, their participation in the immune response is acknowledged by their capacity to produce surfactant proteins A, C and D and a great variety of cytokines and chemokines in response to certain stimulus (Lin et al., 1998). By their location and distribution, these cells are exposed to all type of pathogenic agents that can reach the alveolar space, being then susceptible to the infection. In fact, the possibility that a microorganism finds an epithelial cell is much greater than finding an alveolar macrophage, since comparatively the number of pneumocytes type II surpasses up to 30 times the number of macrophages (Bermudez et al., 2002). In addition, pneumocytes type II may participate as antigen presenting cells, since they express histocompatibility molecules class I and class II, they also express adhesion molecules like ICAM-1, VCAM, LFA-3 and B7 (Corbière et al., 2011; Cunningham et al., 1994).

The ability of $M$. tuberculosis to invade non-phagocytic cells was initially described by Shepard, who described the susceptibility of HeLa cells to M. tuberculosis infection (Shepard, 1955). Years later Mapother and Songer described the intestinal epithelium cell invasion by M. avium, emphasizing the active role of mycobacteria to induce its uptake (Maphoter \& Songer, 1984). Later, Bermudez and Goodman demonstrated the invasion and intracellular replication of $M$. tuberculosis into epithelial cells, using a pneumocytes type II cell line as model (Bermudez \& Goodman, 1996). The presence of M. tuberculosis DNA into pulmonary non-phagocytic cells including epithelial, endothelial and fibroblast from individuals that died by causes other than tuberculosis, confirmed the ability of M. tuberculosis to infect epithelial cells in vivo (Hernandez-Pando et al., 2000). After recognition and acceptance of the ability of $M$. tuberculosis to infect human pneumocytes type II, the next studies were carry out to determine the mechanism responsible of $M$. tuberculosis internalization into the host cell, as well as the mycobacteria ligands involved in the recognition and triggering of 
the endocytosis mechanisms. Nowadays the antimicrobial mechanisms exerted by the nonphagocytic cells to contain $M$. tuberculosis growth are been revealed.

The first studies achieved to explain the invasion mechanism, were made by Bermudez and Goodman, who reported the invasion and replication of $M$. tuberculosis into a cell line of human pneumocytes type II (A549 cells), they described that the internalization process was dependent of actin microfilaments and microtubules, and they suggested that vitronectin receptor and $\beta-1$ integrin were the membrane receptors responsible of $M$. tuberculosis recognition by the epithelial cells (Bermudez \& Goodman, 1996). Later, Reddy and Kumar reported cell membrane projections and membrane ruffling formation during $M$. avium interaction with cells from the respiratory epithelium (Hep-2), and identified two M. avium proteins (31 and $25 \mathrm{kD}$ ), as responsible of this interaction (Reddy \& Kumar, 2000). Our group reported that $M$. tuberculosis entrance into the A549 cells was carried out by an endocytic process known as macropinocytosis, which involves the participation of actin filaments and membrane ruffling formation, in this study we suggested that the viability of the mycobacteria was an indispensable requirement for membrane projections formation and consequently for bacterial entry (Garcia-Perez, et al., 2003). Later, we also reported that entrance of the low-pathogenic M. smegmatis, into the A549 cells was induced by macropinocytosis as well, and we suggested that this endocytic route was not a virulence factor for the mycobacteria (Garcia-Perez et al., 2008). Diverse studies have postulated macropinocytosis as the endocytic pathway responsible of pathogenic microorganisms entrance into non-phagocytic cells (Kerr et al., 2009). It is also known that the establishment of the intracellular signaling for macropinocytosis induction requires an initial stimulation with growth factors, hormones, phorbol-esters and some bacterial products (Swanson, 1989; Swanson \& Watts, 1995; Patel \& Galan, 2006). Some microorganisms, like Salmonella enterica, presents a highly specialized organelle known as secretion system type III (SSTIII), through which proteins responsible of the pathogenicity of this microorganism are transferred into the host cell (Patel \& Galan, 2006). Many of these proteins act imitating functions from the host cell especially those responsible of cytoskeleton rearrangements and macropinocytosis induction. Although M. tuberculosis does not count with a proper SSTIII, a related system known as ESX-1, modulates the early events occurred during mycobacterium infection (DiGiuseppe Champion \& Cox, 2007). Different groups of investigators have reported the production of several molecules that can mediate $M$. tuberculosis interaction with nonphagocytic cells. Arruda and coworkers reported the production of an "invasive like" protein, although they did not show conclusive results on its role in tuberculosis infection (Arruda et al., 1993). The role of the Mce1 protein (one of the members of the Mce protein family) in the entrance of $M$. tuberculosis into the non-phagocytic cells, was demonstrated by using polystyrene microspheres covered with recombinant protein, Chitale and coworkers reported that Mce1 protein was able to induce the formation of "membrane disturbances" in non-phagocytic cells (Chitale et al., 2001). Recently, another group of investigators, reported that Mce3A protein bound to latex particles facilitated uptake by HeLa cells, suggesting that this protein also has a role in M. tuberculosis interaction with host cell (El-Shazly et al., 2007). Also, it has been reported that Mce4A protein facilitates the invasion of HeLa cells by a nonpathogenic E. coli strain expressing Mce4A. Since the Mce4A protein is expressed at the late stage of mycobacterial growth, it has been postulated that this protein besides favoring $M$. tuberculosis entrance, it can play an active role in mycobacterium survival and persistence (Saini et al., 2008). 
Another protein of M. tuberculosis involved in the interaction with the non-phagocytic cells is the heparin binding hemagglutinin (HBHA), which has been reported that induces membrane projections and bacteria internalization into Hep-2 cells (respiratory epithelium) (Reddy and Hayworth, 2002). Additionally, HBHA has been implied in extrapulmonary dissemination of $M$. tuberculosis, hbha gene disruption has deep effects on M. tuberculosis interaction with epithelial cells, but does not affect interaction with macrophages. On the other hand, the mutant strain of HBHA expressed a reduced capacity to colonize spleen, although lung colonization was not affected. These data emphasize the importance of HBHA in extrapulmonary dissemination and remarks the importance of non-phagocytic cells-M. tuberculosis interaction in tuberculosis pathogenesis (Pethe et al., 2001). Menozzi and coworkers reported that HBHA induce endocytosis mediated by receptor through the recognition of proteoglycans containing heparan sulphate (Menozzi et al., 2006). Like other bacterial proteins, mycobacterial HBHA can mimic the function of some cellular proteins being responsible of the modification of diverse cellular activities, including entrance, survival and pathogen dissemination. Recent studies support this theory, Verbelen and collaborators reported that HBHA has a sequence similar to proteins that bound actin, like tropomiosin-1, ezrin-1 and the heavy chain of miosina-9, and their results demonstrated the specific and stable union of HBHA to actin (Verbelen et al., 2008). Another research group showed that HBHA was able to bind to G-actin without altering their nucleation but obstructing actin polymerization; these authors suggest that like profilin, HBHA can affect polymerizationdepolymerization dynamics of F-actin facilitating $M$. tuberculosis mobility into the cytoplasm (Esposito et al., 2011). This report emphasize the importance of HBHA in M. tuberculosis dissemination, since it has demonstrated that HBHA induces membrane protrusions formation, is possible to infer that HBHA may be one of the mycobacterial molecules that can act as "signals for internalization" hence inducing mycobacteria entrance by macropinocytosis, as previously we suggested (Garcia-Perez et al., 2008). Other molecules of $M$. tuberculosis responsible of the invasion of epithelial cells are the mycobacterial DNA-binding protein 1 (MDP1), which promotes A549 cells infection through hyaluronic acid (Aoki et al., 2004); and a group of high active bound peptides (HABPs) of different hypothetical proteins from M. tuberculosis (Rv2301, Rv0180c, Rv0679c, among others), which have shown that facilitates the bound and internalization of latex particles to A549 cells (Cáceres et al., 2011; Cifuentes et al., 2010; Ocampo et al., 2011).

The knowledge of the molecules that participate in M. tuberculosis invasion to nonphagocytic cells is still scarce, basically two surface proteins, Mce and HBHA are the most studied. The great complexity of the mycobacterium cell wall and the external lipids "wall" composition allows us to suggest that most probably not only proteins are involved in mycobacterium invasion, but also some other constituents like mycobacterium-lipids may have an important role. We described that the morphological changes and the cytoskeleton modification of the A549 cells infected by M. tuberculosis were observed in cells with bound or internalized bacteria, but also were observed in cells without bacteria, this made us to suggest that those changes could be induced also by secretion molecules (Garcia-Perez et al, 2003; Garcia-Perez et al., 2008). Chopra and colleagues speculated that the nucleotide diphosphate kinase (Ndk), a M. tuberculosis secretion protein, which acts as a GTPases protein activator may contribute to internalization of $M$. tuberculosis into the host cell by 
inducing cytoskeleton reorganization (Chopra et al., 2004). Still there is a need to elucidate and explain the role of $M$. tuberculosis secretion molecules that could be related to invasion and survival of mycobacteria into the non-phagocytic cells.

M. tuberculosis entrance into the non-phagocytic cells is not a circumstantial event, it must be induce by mycobacterial product(s), the best candidates could be mycobacterial actively secreted products that could reach many cells in a short time, and these molecules can be recognized as the "first signal". This first signal initiates the intracellular signaling cascades that leads to the formation of membrane protrusions necessary to internalize the bacillus, but this event apparently is not enough to assure mycobacterial internalization. During the non-phagocytic cell infection event, only few cells will be finally infected; if we infect simultaneously, with the same mycobacterial cell suspension, during the same time, a monolayer of macrophages and a monolayer of non-phagocytic cells (for instance lung epithelial cells), up to $90 \%$ of the macrophages will be infected compared to $10 \%$ of epithelial cells (Garcia-Pérez et al., 2003). So, most probably another signal, the "second signal" is needed to assure that mycobacteria will be internalized by the non-phagocytic cell, and most probably this "second signal" will depend on the physical interaction of some bacterium molecule (PAMP) with a receptor molecule on the host cell (PRR). For the case of macrophages, already we described the variety of receptors involved in the interaction mycobacteria:phagocytic cell. With respect to the non-phagocytic cells, there are few studies of cell receptors involved in mycobacterium invasion. Given the frequency and ubiquitous distribution of glycosaminoglycans on the epithelial cell surface, it has been proposed that these molecules are good candidates for the union and penetration of pathogenic microorganisms in the tissues (Menozzi et al., 1996). The evidences indicate that cells from the respiratory epithelium express PRRs, specifically TLRs, making them able to contribute to the establishment of the pulmonary innate immune response. In the pulmonary epithelium, 11 TLRs are expressed, along with CD14, an important element for TLR4 function, these molecules have been involved in the recognition of pathogens by these epithelial cells (Bals \& Hiemstra, 2004; Gribar et al., 2008). Interestingly, Lee and collaborators reported that $M$. tuberculosis actively induce Dectin-1 receptor expression by A549 cells; Dectin-1 is a classical receptor for fungi, and is expressed mainly by myeloid cells. They established that for Dectin-1 expression, the participation of TLR2 and ROS were crucial. In addition, the authors demonstrated that Dectin-1 and TLR2 were equally responsible of the early activation of Src in the epithelial cells stimulated by M. tuberculosis, and suggest that Dectin-1 in the epithelial cell contribute to mycobacterial survival (Lee et al., 2009) (Fig.1).

\subsection{Endothelial cells infection by M. tuberculosis}

The endothelium is composed of a single layer of thin flattened cells known as endothelial cells, that lines internal body cavities and the lumens of vessels, endothelial cells had a mesodermal origin. Endothelial cells participate in several cellular functions like vasoconstriction and vasodilation (blood pressure control), angiogenesis, inflammation, etc., so endothelial cells contribute to the whole homeostasis of the organism. In cases of bacteraemia or viraemia, endothelial cells are among the first cells to be in contact with microbial pathogens and are also among the first cells that respond to endogenous 


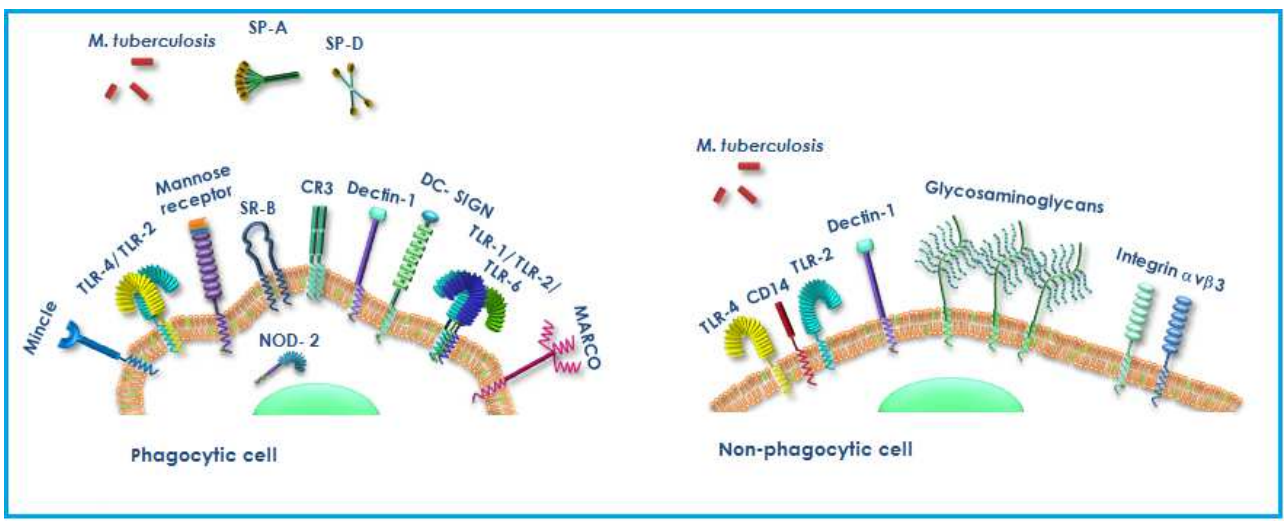

Fig. 1. Non-phagocytic and phagocytic cell receptors involved in M. tuberculosis recognition.

molecules released in events of tissue damage (Opitz et al., 2009). Different research groups have demonstrated $M$. tuberculosis interaction with the endothelial cells; in the first study, Birkness and coworkers used a bilayer model of epithelial and endothelial cells, and they demonstrated adhesion, internalization and passage of $M$. tuberculosis through the bilayer (Birkness et al., 1999). Later, the study of Bermudez and collaborators established that $M$. tuberculosis crosses the alveolar wall to reach the endothelial cell, hence suggesting the ability of $M$. tuberculosis to disseminate (Bermudez et al., 2002). The presence of $M$. tuberculosis DNA in lung endothelial cells of human samples from cadaveric donors from countries with high TB incidence, confirmed the infection of endothelial cells in in vivo situations (Hernandez-Pando et al., 2000). The first oriented study to establish some features of endothelial cell infection by $M$. tuberculosis was performed by Metha and coworkers; in this work, authors describe the interaction of $M$. tuberculosis with two endothelial cell lines, one from human lung (HULEC) and the other from human foreskin (HMEC-1). The authors determined that $M$. tuberculosis may bound, enter and survive better into the pulmonary cell line (HULEC), than in the skin cell line HMEC-1, suggesting that lung cells are a better niche for mycobacterial replication (Metha et al., 2006). Recently, our group reported the innate response of human umbilical vein endothelial cells (HUVEC) against M. tuberculosis, $M$. abscessus and M. smegmatis infection. The study demonstrated that although the three different mycobacterium species were internalized, the intracellular fate of each strain was different. The mechanism responsible of mycobacteria entrance into the endothelial cells is still unknown, but we found that during mycobacteria internalization the endothelial cells display cytoskeleton rearrangements and the magnitude of those changes was different for each mycobacterium strain, for instance, the more virulent mycobacteria induced the most dramatic rearrangements. It is necessary to determine if macropinocytosis is also the mechanisms responsible of mycobacterial uptake by endothelial cells, as it occurs for epithelial cells (Garcia-Perez et al., 2003). Contrary to other cell models, intracellular $M$. tuberculosis did not replicate, or was eliminated by HUVECs, resembling a "latency stage", that could be triggered by the high NO levels induced at early times of the infection (GarciaPerez et al., 2011). 
Up today there are not conclusive studies on the molecules responsible of $M$. tuberculosis recognition by endothelial cells, however is known that endothelial cells express a great variety of PRRs through which they interact with different pathogens (Opitz et al., 2009). The few reports on mycobacterial molecules involved in endothelial recognition indicate that phosphatidylinositide mannoside (PIMs) can act as adhesins that mediate $M$. tuberculosis bounding to non-phagocytic cells (Hoppe et al., 1997). Another study indicates that HBHA induces acting filament reorganization in a confluent endothelial cells monolayer, which suggests that this protein may also be involved in the recognition of $M$. tuberculosis by endothelial cells (Menozzi et al., 2006).

\subsection{Interaction of $M$. tuberculosis with other non-phagocytic cells}

M. tuberculosis interaction with other non-phagocytic cells like adipocytes or fibroblasts has been reported, although few reports exist on the matter. A recent study demonstrated that adipocytes are susceptible to $M$. tuberculosis invasion but in these cells, M. tuberculosis persists in a non-replicative state. Mycobacterial recognition by adipocytes was mediated by scavenger receptors. The authors suggest that due to the abundance and wide distribution of fatty tissues in the human body, adipocytes may represent an ideal reservoir for persistent tuberculosis bacilli (Neyrolles et al., 2006).

Fibroblasts and epithelial cells constitute two of the main structural cell lineages of the lung, in tuberculosis, fibroblasts are present in the periphery of granulomas; they synthesize extracellular matrix proteins that are required for the maintenance and repairing of the lung; in addition they produce cytokines and chemokines that allow leukocyte recruitment and activation (Suzuki et al., 2008). In spite of the physiological relevance of the fibroblasts, its interaction with pathogens, specifically with $M$. tuberculosis has been scarcely explored. The first study of the matter, performed by Rastogi and coworkers, demonstrated that $M$. tuberculosis and M. avium can infect a murine fibroblast cell line, and in response to the infection, fibroblasts secreted several chemical mediators that promote mycobacterium elimination by macrophages (Rastogi et al., 1992). Up today, two additional studies demonstrated the role of the fibroblasts in the mycobacterial infection. In the first study, Hernandez-Pando and coworkers reported the presence of mycobacterial DNA in lung fibroblasts (among other cells) from cadaveric donors that die for causes different to tuberculosis; these individuals lived in countries with high tuberculosis prevalence. These data suggest that a previous in vivo $M$. tuberculosis infection was established and controlled in those individuals and reveal the importance of lung fibroblast in the response (Hernandez-Pando et al., 2000). The second study confirms that fibroblast are susceptible of $M$. tuberculosis infection; and describes the multiplication features of several strains and mutants of $M$. tuberculosis into human lung fibroblast and rat lung fibroblasts, although they found that human fibroblast are more permissive to mycobacterial growth. Contrary to several studies with other cell lineages like epithelial or endothelial cells, these authors report that in fibroblast, $M$. tuberculosis internalization is actin and tubulin independent, and conclude that mycobacteria do no requires cell host cytoskeleton reorganization to be internalized (Ferrer et al., 2009). Preliminary results of our group demonstrate that infection of mouse lung fibroblasts (MLg cell line) by M. tuberculosis induce actin mobilization and membrane ruffling contrary to those observations described by Ferrer and coworkers (Fig. 2). The discrepancy in these results forces to make new studies to clarify and precise the 
mechanism responsible of $M$. tuberculosis internalization into fibroblasts, and to determine the mycobacterial molecules and the cell receptors involved in the recognition and triggering of this event. In addition, it is necessary determine the defense mechanisms elicited by the fibroblasts to contain the mycobacterial infections.
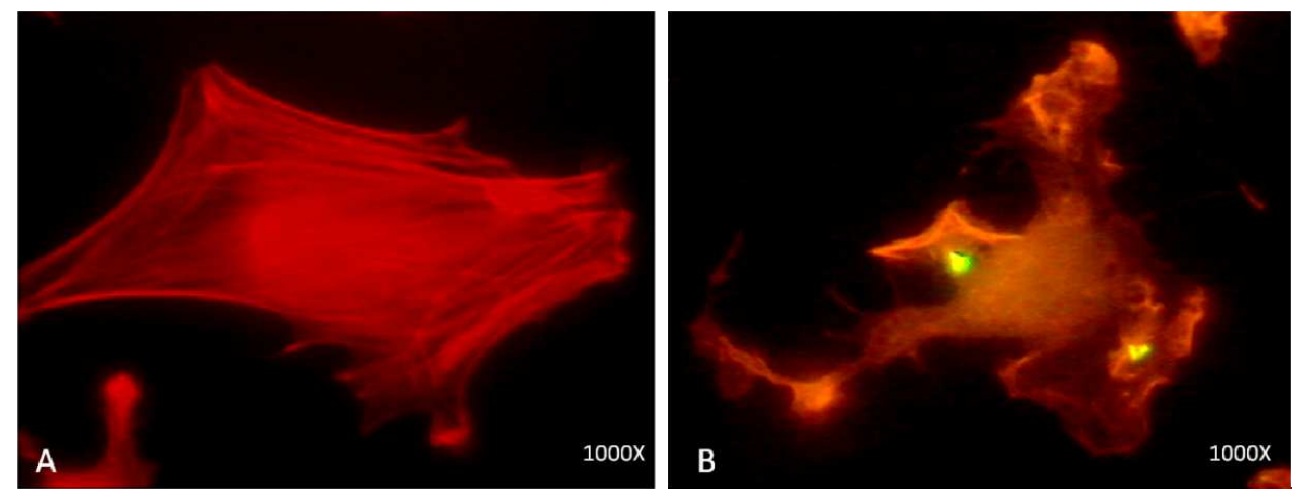

Fig. 2. Interaction of $M$. tuberculosis with fibroblasts. Cells were infected during $1 \mathrm{~h}$ with $M$. tuberculosis. Before the infection, bacilli were stained with fluorescein isothiocyanate (FITC, green color). After infection, actin filaments were labeled with rhodamine-phalloidin (red). A) Uninfected cell showing actin filaments longitudinally distributed. B) Infected cell showing membrane protrusions and membrane ruffling in contact with mycobacteria.

\section{Innate immune response of non-phagocytic infected by $M$. tuberculosis}

Phagocytic cells like macrophages, neutrophils and monocytes have a crucial role in the defense against infections; they are responsible of bacterial phagocytosis and their elimination. They count with well adapted systems for bacterial recognition and exhibit sophisticate and highly effective mechanisms to eliminate the pathogenic microorganisms. Production of reactive oxygen and reactive nitrogen species, cytokines and chemokines production, degradative enzymes production, and antimicrobial peptide production are some of the elements displayed by the phagocytic cells to contain and kill pathogens. On the other hand, pathogenic microorganisms have developed numerous mechanisms to evade the antimicrobial arsenal and to guarantee their survival and persistence. In particular, $M$. tuberculosis has developed several mechanisms to avoid the hostile environment of the macrophages and to persist within them: a) inhibition of the phago-lysosome fusion, b) inhibition of the phago-lysosome acidification, c) recruitment and retention of TACO protein (tryptophan- aspartate containing coat protein) on phagosomes to prevent fusion with lysosome and d) expression of proteins and lipids for protection against the oxidative stress (Meena \& Rajni, 2010). Also the ability of mycobacterium to enter into non-phagocytic cells is another mechanism of immunological evasion, since mycobacteria "hided" in these cells could skip hostile environment of the macrophages and create an ideal niche for its replication and establishment. Nevertheless, recent evidences suggest that non-phagocytic cells have an important role in the immune response against mycobacteria and these cells have the potentially to exert potent antimycobacterial mechanisms (Garcia-Perez et al., 2011; Kwon et al., 1998; Sharma et al., 2007). Besides, we demonstrated that the intracellular 
destiny of $M$. tuberculosis will be dictated by the cell type infected, hence while in epithelial cells $M$. tuberculosis survives and replicates, in the endothelial cells tends to persist without showing replication (Garcia-Perez et al., 2011). We consider that non-phagocytic cells can actively respond to $M$. tuberculosis infection, but the magnitude and diversity of their response can be modulated by the bacillus to guarantee its survival, persistence and/or dissemination. Kwon and George demonstrated that epithelial cells are able to produce nitric oxide (NO) in response to cytokines like IL-1 and IFN-ץ (Kwon \& George, 1999) and also in response to $M$. tuberculosis (Kwon et al., 1998). Later, Roy and collaborators established that direct infection of epithelial cells by $M$. tuberculosis, stimulates the novo production of NO via iNOS, although they demonstrated that the low levels of NO produced during the direct-mycobacterial stimulation, were not sufficient to kill the bacilli, however NO production by cells infected and simultaneously stimulated with cytokines was sufficient to kill the mycobacteria and to reduce the bacterial load (Roy et al., 2004). We reported that endothelial cells produce $\mathrm{NO}$ in response to mycobacterial infection and we found that NO concentrations correlated with the capacity of infective bacteria to induce modifications in the actin cytoskeleton. We demonstrated that a high NO production does not correlate with the diminution of the bacterial load, on the contrary, the mycobacterium with the greater intracellular replication (M. abscessus), induced the greater amount of NO. In comparison, the mycobacterium that induced the lower NO levels was eliminated $(M$. smegmatis), but induced the higher ROS production, which allowed us to suggest that ROS have a more important role for mycobacterial elimination than NO. Interestingly, in the endothelial cells, M. tuberculosis exhibited a non-replicative state, resembling the latency state characteristic of tuberculosis. In these cells, $M$. tuberculosis triggered intermediate levels of NO compared with the other two mycobacteria, but at very early stages of infection, a "burst of NO" production was observed, and a rapid diminution of this metabolite proceed to this event (Garcia-Perez et al., 2011). Based on these results, we can suggest that the ability of the mycobacteria to modulate NO production by the endothelial cells will determine, in great extent, its final intracellular fate.

The importance of ROS in the innate immunity was recognized initially in the phagocytic cells, which under certain stimuli generate the "respiratory burst". ROS production is related to the activity of the NADPH oxidases, although ROS may be produced by other mechanisms (West et al., 2011). In the phagocytic cells, the NADPH oxidase responsible of ROS production is NOX2. In recent years, 7 isoforms of NOX/DUOX enzymes have been described, and their distribution and function in different cells or tissues is been recognized (Krause, 2004). ROS have an ample variety of biological activities, participating not only as antimicrobial agent (which is one of the least sophisticated activities). ROS participate in hormone biosynthesis, intracellular signaling, blood pressure control, etc. (Krause, 2004). At the moment it has been recognized that some non-phagocytic cells express some members of this oxidase family; one of the most studied cells are the pneumocytes type II A549 cells, which has been reported that express NOX1, NOX2, DUOX 1 and DUOX2 (Kolářová et al., 2010), and although in these cells the role of ROS for pathogens elimination has not been studied, there are reports that indicate the importance of ROS generation in the modulation of the immune response. In the infection of epithelial cells by M. tuberculosis, Lee and collaborators reported that ROS are produced via the activation of Src, after Dectin-1 engagement, Dectin-1 is a crucial receptor that contributes to mycobacterium 
internalization, the expression of pro-inflammatory mediators and the establishment of an effective antimicrobial environment, constituted in part by ROS (Lee et al., 2009). In the endothelial cells, Van Buul and coworkers, reported the differential expression and location of NOX2 and NOX4, whereas NOX4 was located in the endoplasmic reticulum, the regulating proteins of NOX2 were located and associated to actin present at membrane protrusions and ruffles; in this work the authors correlated ROS scavenging activity with an impair of cytoskeleton rearrangement and the formation of confluent monolayers (Van Buul et al., 2005). We reported that endothelial cells produce ROS in response to the mycobacterium infection, and we correlated a high ROS production with mycobacterium elimination (Garcia-Perez et al., 2011). The role of ROS as direct M. tuberculosis effectors is still controversial, however ROS indirectly, may contribute to M. tuberculosis elimination, for example the signaling route dependent of ROS and NOX2, is crucial for the achievement of the antimycobacterial effect of cathelicidin, an antimicrobial peptide induced by vitamin D3 in macrophages (Yang et al., 2009).

The participation of antimicrobial peptides or defensins in M. tuberculosis infection is a current issue. Defensin production by some non-phagocytic cells infected with mycobacteria has been reported; Rivas-Santiago and collaborators, found that in vitro infection of pneumocytes (A549 cells) by M. tuberculosis, induced human $\beta$-defensin 2 (HBD-2) production, immunolocalization with colloidal gold demonstrated HBD-2 associated to damaged bacillus, suggesting the antimicrobial effect of this peptide (Rivas-Santiago et al., 2005). Later, the same group reported the expression and production of another antimicrobial peptide cathelicidin LL37, by epithelial cells infected by M. tuberculosis (RivasSantiago et al., 2008). In a mouse model of chronic pulmonary tuberculosis and latent tuberculosis, defensin expression was analyzed; the results demonstrated that $\beta$-defensin-3 (MBD-3), $\beta$-defensin-4 (MBD4) and CRAMP (the mouse equivalent of the cathelicidin LL37) were expressed by different cell types including lung epithelial cells. In the progressive tuberculosis model, initial production of MBD3 and MBD4 correlated with the transitory control of mycobacterial growth, although their expression diminished at the late stage of the disease. In the latent infection, MBD3 and MBD4 were expressed continuously, but after disease reactivation, their production was abrogated. CRAMP expression was high in the progressive phase of the disease and the protein was observed in different structures of the mycobacteria. The authors of these studies conclude that both defensins and cathelicidin participate in mycobacterial containment, not only by the direct activity against the bacteria, but by their recognized chemotactic activity (Rivas-Santiago et al., 2006; Castañeda-Delgado et al., 2010). Another antimicrobial peptide involved in the defense against $M$. tuberculosis is hepcidin. Recently, the production of this antimicrobial peptide by the epithelial cells stimulated with ManLAM and PIMs from M. tuberculosis was reported, and proposed that the antimicrobial activity was mediated by a reduction in the iron available at the alveolar space (Sow et al., 2011). We recently reported that M. tuberculosis infection of endothelial cells stimulated HBD-1 production, and we proposed that this defensin could have an important role in the mycobacterial growth control observed in this model (Garcia-Perez et al., 2011). The direct antimycobacterial role of HBD1 is not determined so far.

One of the actual hypotheses is that the environment surrounding the non-phagocytic cells is crucial for their activation and preparation for bacterial elimination. Greco and collaborators reported that the enriched lysophospholipid pulmonary microenvironment 
protects pneumocytes type II from cytotoxicity induced by $M$. tuberculosis, and increases the antimycobacterium response by promoting acidification of endosomal compartments (Greco et al., 2010). Desvignes and Ernst demonstrated that epithelial and endothelial cells after IFN-y stimulation express a better response for $M$. tuberculosis growth control. These authors established that one of the mechanisms involved in the response induced by IFN- $\gamma$ is expression of indoleamine-2,3-dioxygenase (IDO) and regulation of the expression of IL-17 (Desvignes \& Ernst, 2009). The capacity of epithelial cells to improve their response after IFN- $\gamma$ exposure is supported by the observation that cells infected by $M$. tuberculosis express elevated levels of the receptor specific for this cytokine (Sharma et al., 2007).

\section{References}

Akira, S.; Uematsu, S. \& Takeuchi O. (2006). Pathogen recognition and innate immunity. Cell, Vol.124, No.4, (February 2006), pp. 783-801, ISSN 1097-4172

Anderson, K.; Evers, D. \& Rice, K. (2008). Structure and Function of Mammalian Carbohydrate-Lectin Interactions, In: Glycoscience, Fraser- Reid, B.; Tatsuta, K. \& Thiem, J. pp. (2445- 2482), Springer-Verlag Berlin Heidelberg, http://dx.doi.org/10.1007/978-3-540-30429-6_63

Aoki, K.; Matsumoto, S.; Hirayama, Y.; Wada, T.; Ozeki, Y.; Niki, M.; Domenech, P.; Umemori, K.; Yamamoto, S.; Mineda, A.; Matsumoto, M. \& Kobayashi, K. (2004). Extracellular mycobacterial DNA-binding protein 1 participates in mycobacteriumlung epithelial cell interaction through hyaluronic acid. The Journal of biological chemistry, Vol.279, No.38, (September 2004), pp. 39798-39806, ISSN 1083-351X

Appelmelk, B.; van Die, I.; van Vliet, S.; Vandenbroucke-Grauls, C.; Geijtenbeek, T. \& van Kooyk, Y. (2003). Cutting edge: carbohydrate profiling identifies new pathogens that interact with dendritic cell-specific ICAM-3-grabbing nonintegrin on dendritic cells. Journal of Immunolgy, Vol.170, No.4, (February 2003), pp. 1635-1639, ISSN 1550-6606

Areschoug, T. \& Gordon, S. (2009). Scavenger receptors: role in innate immunity and microbial pathogenesis. Cellular microbiology, Vol.11, No.8, (August 2009) pp. 11601169, ISSN 1462-5822

Arredouani, M.; Palecanda, A.; Koziel, H.; Huang, Y.; Imrich, A.; Sulahian, T.; Ning, Y.; Yang, Z.; Pikkarainen, T.; Sankala, M.; Vargas, S.; Takeya, M.; Tryggvason, K. \& Kobzik, L. (2005). MARCO is the major binding receptor for unopsonized particles and bacteria on human alveolar macrophages. The Journal of immunology, Vol.175, No.9, (November, 2005), pp. 6058-642005, ISSN 1550-6606

Arruda, S.; Bomfim, G.; Knights, R.; Huima-Byron, T. \& Riley L. (1993). Cloning of an M. tuberculosis DNA fragment associated with entry and survival inside cells. Science, Vol.10, No.261, (September 1993), pp. 1454-1457, ISSN 1095-9203

Astarie-Dequeker, C.; N’Diaye, E.; Le Cabec, V.; Ritting, M.; Prandi, J. \& MaridonneauParini I. (1999). The mannose receptor mediates uptake of pathogenic and nonpathogenic mycobacteria and bypasses bactericidal responses in human macrophages. Infection and immunity, Vol.67, No.2, (February 1999), pp. 469-477, ISSN 1098-5522

Bafica, A.; Scanga, C.; Feng, C.; Leifer, C.; Cheever, A. \& Sher, A. (2005). TLR9 regulates Th1 responses and cooperates with TLR2 in mediating optimal resistance to 
Mycobacterium tuberculosis. The Journal of experimental medicine, Vol.202, No.12, (December 2005), pp. 1715-1724, ISSN 1540-9538

Bals, R. \& Hiemstra, P. (2004). Innate immunity in the lung: how epithelial cells fight against respiratory pathogens. The European respiratory journal, Vol.23, No.2, (February 2004), pp. 327-333, ISSN 1399-3003

Beharka, A.; Gaynor, C.; Kang, B.; Voelker, D.; McCormack, F. \& Schlesinger L. (2002). Pulmonary surfactant protein A up-regulates activity of the mannose receptor, a pattern recognition receptor expressed on human macrophages. The Journal of immunology, Vol.169, No.7, (October 2002), pp. 3565-3573, ISSN 1550-6606

Bermudez, L. \& Goodman J. (1996). Mycobacterium tuberculosis invades and replicates within type II alveolar cells. Infection and immunity, Vol.64, No.4, (April 1996), pp. 1400-1406, ISSN 1098-5522

Bermudez, L.; Sangari, F.; Kolonoski, P.; Petrofsky, M. \& Goodman, J. (2002). The efficiency of the translocation of Mycobacterium tuberculosis across a bilayer of epithelial and endothelial cells as a model of the alveolar wall is a consequence of transport within mononuclear phagocytes and invasion of alveolar epithelial cells. Infection and immunity, Vol.70, No.1, (January 2002), pp. 140-146, ISSN 1098-5522

Birkness, K.; Deslauriers, M.; Bartlett, J.; White, E.; King, C. \& Quinn F. (1999). An in vitro tissue culture bilayer model to examine early events in Mycobacterium tuberculosis infection. Infection and immunity, Vol.67, No.2, (February 1999), pp. 653-658, ISSN 1098-5522

Bowdish, D.; Sakamoto, K.; Kim, M.; Kroos, M.; Mukhopadhyay, S.; Leifer, C.; Tryggvason, K.; Gordon, S. \& Russell D. (2009). MARCO, TLR2, and CD14 are required for macrophage cytokine responses to mycobacterial trehalose dimycolate and Mycobacterium tuberculosis. PLoS pathogens, Vol.5, No.6, (June 2009), pp. e1000474, ISSN 1553-7374

Branger, J.; Leemans, J.; Florquin, S.; Weijer, S.; Speelman, P. \& Van Der Poll, T. (2004). Tolllike receptor 4 plays a protective role in pulmonary tuberculosis in mice. International immunology, Vol.16, No.3, (March 2004), pp. 509-516, ISSN 1460-2377

Brown, G.; Herre, J.; Williams, D.; Willment, J.; Marshall, A. \& Gordon, S. (2003). Dectin-1 mediates the biological effects of beta-glucans. The Journal of experimental medicine, Vol.197, No.9, (May 2003), pp. 1119-1124, ISSN 1540-9538

Bulut, Y.; Faure, E.; Thomas, L.; Equils, O. \& Arditi, M. (2001). Cooperation of Toll-like receptor 2 and 6 for cellular activation by soluble tuberculosis factor and Borrelia burgdorferi outer surface protein A lipoprotein: role of Toll-interacting protein and IL-1 receptor signaling molecules in Toll-like receptor 2 signaling. The Journal of immunology, Vol.167, No.2, (July 2001), pp. 987-994, ISSN 1550-6606

Bulut, Y.; Michelsen, K.; Hayrapetian, L.; Naiki, Y.; Spallek,R.; Singh, M. \& Arditi, M. (2005). Mycobacterium tuberculosis heat shock proteins use diverse Toll-like receptor pathways to activate pro-inflammatory signals. The Journal of biological chemistry, Vol.280, No.22, (June 2005), pp. 20961-20967, ISSN 1083-351X

Cáceres, S.; Ocampo, M.; Arévalo-Pinzón, G.; Jimenez, R.; Patarroyo.; M.E \& Patarroyo,; M.A. (2011). The Mycobacterium tuberculosis membrane protein Rv0180c: Evaluation of peptide sequences implicated in mycobacterial invasion of two human cell lines. Peptides. Vol. 32, No. 1, (January 2011), pp. (1-10), ISSN 1873-5169 
Castañeda-Delgado, J.; Hernández-Pando, R.; Serrano, C.; Aguilar-León, D.; León-Contreras, J.; Rivas-Santiago, C.; Méndez, R.; González-Curiel, I.; Enciso-Moreno, A, \& RivasSantiago, B. (2010). Kinetics and cellular sources of cathelicidin during the course of experimental latent tuberculous infection and progressive pulmonary tuberculosis. Clinical and experimental immunology, Vol.161, No.3, (September, 2010), pp. 542-550, ISSN 1365-2249

Chieppa,M.; Bianchi, G.; Doni, A.; Del Prete, A.; Sironi, M.; Laskarin, G.; Monti, P.; Piemonti, L.; Biondi, A.; Mantovani, A.; Introna, M.\& Allavena, P. (2003). Cross-linking of the mannose receptor on monocyte-derived dendritic cells activates an antiinflammatory immunosuppressive program. The Journal of Immunology, Vol.171, No.9, (November 2003), pp. 4552-4560, ISSN 1550-6606

Chitale, S.; Ehrt, S.; Kawamura, I.; Fujimura, T.; Shimono, N.; Anand, N.; Lu, S.; CohenGould, L. \& Riley, L. (2001). Recombinant Mycobacterium tuberculosis protein associated with mammalian cell entry. Cellular microbiology, Vol.3, No.4, (April 2001), pp. 247-254, ISSN 1462-5822

Chopra, P.; Koduri, H.; Singh, R.; Koul, A.; Ghildiyal, M.; Sharma, K.; Tyagi, A. \& Singh, Y. (2004). Nucleoside diphosphate kinase of Mycobacterium tuberculosis acts as GTPase-activating protein for Rho-GTPases. FEBS letters, Vol.571, No.1, (July 2004), pp. 212-156, ISSN 1873-3468

Cifuentes, D.; Ocampo, M.; Curtidor, H.; Vanegas, M.; Forero, M.; Patarroyo, M.E. \& Patarroyo, M.A. (2010). Mycobacterium tuberculosis Rv0679c protein sequences involved in host-cell infection: potential $\mathrm{TB}$ vaccine candidate antigen. BMC microbiology, Vol.10, No.109, (2010 April), ISSN 1471-2180

Corbière, V.; Dirix, V.; Norrenberg, S.; Cappello, M.; Remmelink, M. \& Mascart, F. (2011). Phenotypic characteristics of human type II alveolar epithelial cells suitable for antigen presentation to T lymphocytes. Respiratory research, Vol.12, No.15, (January, 2011), ISSN 1465-993X

Court, N.; Vasseur, V.; Vacher, R.; Frémond, C.; Shebzukhov, Y.; Yeremeev, V.; Maillet, I.; Nedospasov, S.; Gordon, S.; Fallon, P.; Suzuki, H.; Ryffel, B. \& Quesniaux, V. (2010). Partial redundancy of the pattern recognition receptors, scavenger receptors, and C-type lectins for the long-term control of Mycobacterium tuberculosis infection. The Journal of immunology, Vol.184, No.12, (June 2010), pp. 7057-7070, ISSN A341550-6606

Cunningham, A.; Milne, D.; Wilkes, J.; Dark, J.; Tetley, T. \& Kirby, J. (1994). Constitutive expression of MHC and adhesion molecules by alveolar epithelial cells (type II pneumocytes) isolated from human lung and comparison with immunocytochemical findings. Journal of cell science, Vol.107, (February 1994), pp. 443-449, ISSN 1477-9137

Desvignes, L. \& Ernst, J. (2009). Interferon-gamma-responsive nonhematopoietic cells regulate the immune response to Mycobacterium tuberculosis. Immunity, Vol. 31 No.6, (December 2009), pp. 974-985, ISSN 1097-4180

DiGiuseppe Champion, P. \& Cox, J. (2007). Protein secretion systems in Mycobacteria. Cellular microbiology, Vol.9, No.6, (June 2007) pp. 1376-1384, ISSN 1462-5822

Dinadayala, P.; Lemassu, A.; Granovski, P.; Cerantola, S.; Winter, N. \& Daffe, M. (2004). Revisiting the structure of the anti-neoplastic glucans of Mycobacterium bovis 
Bacille Calmette-Guerin: structural analysis of the extracellular and boiling water extract-derived glucans of the vaccine substrains. The Journal of biological chemistry, Vol.279, No.13, March 2004, pp. 12369-12378, ISSN 1083-351X

Divangahi, M.; Mostowy, S.; Coulombe, F.; Kozak, R.; Guillot, L.; Veyrier, F.; Kobayashi, K.; Flavell, R.; Gros, P.\& Behr, M. (2008). NOD2-deficient mice have impaired resistance to Mycobacterium tuberculosis infection through defective innate and adaptive immunity. The Journal of immunology, Vol.181, No.10, (November 2008), pp. 7157-7165, ISSN 1550-6606

Doz, E.; Rose, S.; Nigou, J.; Gilleron, M.; Puzo, G.; Erard, F.; Ryffel, B. \& Quesniaux, V. (2007). Acylation determines the toll-like receptor (TLR)-dependent positive versus TLR2-, mannose receptor-, and SIGNR1-independent negative regulation of proinflammatory cytokines by mycobacterial lipomannan. The Journal of biological chemistry, Vol.238, No.36, (September 2007), pp. 26014-26025, ISSN 1083-351X

El-Shazly, S.; Ahmad, S.; Mustafa, A.; Al-Attiyah, R. \& Krajci, D. (2007). Internalization by HeLa cells of latex beads coated with mammalian cell entry (Mce) proteins encoded by the mce3 operon of Mycobacterium tuberculosis. Journal of medical microbiology, Vol.56, No.9, (September 2007), pp. 1145-1151, ISSN 1473-5644

Ernst, J. (1998). Macrophage receptors for Mycobacterium tuberculosis. Infection and immunity, Vol.66, No.4, (April 1998), pp. 1277-1281, ISSN 1098-5522

Esposito, C.; Marasco, D.; Delogu, G.; Pedone, E. \& Berisio R. (2011). Heparin-binding hemagglutinin HBHA from Mycobacterium tuberculosis affects actin polymerisation. Biochemical and biophysical research communications, Vol.410, No.2, (July 2011), pp. 339-44, ISSN 1090-2104

Febbraio, M.; Hajjar, D. \& Silverstein, R. (2001). CD36: a class B scavenger receptor involved in angiogenesis, atherosclerosis, inflammation, and lipid metabolism. The Journal of clinical investigation, Vol.108, No.6, (September 2001), pp. 785-791, ISSN 1558-8238

Fels, A. \& Cohn, Z. (1986). The alveolar macrophage. Journal of applied physiology, Vol.60, No.2, (February 1986), pp. 353-369, ISSN 1522-1601

Feng, C.; Scanga, C.; Collazo-Custodio, C.; Cheever, A.; Hieny, S.; Caspar, P. \& Sher, A. (2003). Mice lacking myeloid differentiation factor 88 display profound defects in host resistance and immune responses to Mycobacterium avium infection not exhibited by Toll-like receptor 2 (TLR2)- and TLR4-deficient animals. The Journal of immunology, Vol.171, No.9, (November 2003), pp. 4758-4764, ISSN 1550-6606

Ferguson, J.; Voelker, D.; McCormack, F. \& Schlesinger, L. (1999) Surfactant protein D binds to Mycobacterium tuberculosis bacilli and lipoarabinomannan via carbohydratelectin interactions resulting in reduced phagocytosis of the bacteria by macrophages. The Journal of immunology, Vol.163, No.1, (July 1999), pp. 312-321, ISSN 1550-6606

Ferrer, N.; Gómez, A.; Soto, C.; Neyrolles, O.; Gicquel, B.; García-Del Portillo, F. \& Martín, C. (2009) Intracellular replication of attenuated Mycobacterium tuberculosis phoP mutant in the absence of host cell cytotoxicity. Microbes and infection, Vol.11, No.1, (January 2009), pp. 115-122, ISSN 1769-714X

Ferwerda, G.; Girardin. S.; Kullberg, B.; Le Bourhis, L.; de Jong, D.; Langenberg, D.; van Crevel, R.; Adema, G.; Ottenhoff, T.; Van der Meer, J. \& Netea, M. (2005). NOD2 and toll-like receptors are nonredundant recognition systems of Mycobacterium 
tuberculosis. PLoS pathogens, Vol.1, No.3, (November 2005), pp. 279-285, ISSN 15537374

García-Pérez, B.; Hernández-González, J.; García-Nieto, S. \& Luna-Herrera J. (2008). Internalization of a non-pathogenic mycobacteria by macropinocytosis in human alveolar epithelial A549 cells. Microbial pathogenesis, Vol.45, No.1, (July 2008), pp. 1-6, ISSN 1096-1208

García-Pérez, B.; Mondragón-Flores, R. \& Luna-Herrera, J. (2003). Internalization of Mycobacterium tuberculosis by macropinocytosis in non-phagocytic cells. Microbial pathogenesis. Vol. 35, No. 2, (Agosto 2003), pp. 49-55, ISSN 1096-1208

García-Pérez, B.; Villagómez-Palatto, D.; Castañeda-Sánchez, J.; Coral-Vázquez, R.; RamírezSánchez, I.; Ordoñez-Razo, R. \& Luna-Herrera, J. (2011) Innate response of human endothelial cells infected with mycobacteria. Immunobiology, Vol.216, No.8, (August 2011), pp. 925-935, ISSN 1878-3279

Gaynor, C.; McCormack, F.; Voelker, D.; McGowan, S. \& Schlesinger, L. (1995). Pulmonary surfactant protein A mediates enhanced phagocytosis of Mycobacterium tuberculosis by a direct interaction with human macrophages. The Journal of immunology, Vol.155, No.11, (December 1995), pp. 5343-5351, ISSN 1550-6606

Gehring,A.; Dobos, K.; Belisle, J.; Harding, C. \& Boom, W. (2004). Mycobacterium tuberculosis LprG (Rv1411c): a novel TLR-2 ligand that inhibits humanmacrophage class II MHC antigen processing. The Journal of immunology, Vol.173, No.4, (August 2004), pp. 2660-2668, ISSN 1550-6606

Geijtenbeek, T.; Van Vliet, S.; Koppel, E.; Sanchez-Hernandez, M.; Vandenbroucke-Grauls, C.; Appelmelk, B. \& Van Kooyk, Y. (2003). Mycobacteria target DC-SIGN to suppress dendritic cell function. The Journal of experimental medicine, Vol.197, No.1, (January 2003), pp. 7-17, ISSN 1540-9538

Geurtsen, J.; Chedammi, S.; Mesters, J.; Cot, M.; Driessen, N.; Sambou, T.; Kakutani, R.; Ummels, R.; Maaskant, J.; Takata, H.; Baba, O.; Terashima, T.; Bovin, N.; Vandenbroucke-Grauls, C.; Nigou, J.; Puzo, G.; Lemassu, A.; Daffé, M. \& Appelmelk, B. (2009). Identification of mycobacterial alpha-glucan as a novel ligand for DC-SIGN: involvement of mycobacterial capsular polysaccharides in host immune modulation. The Journal of immunology, Vol.183, No.8, (October 2009), pp. 5221-5231, ISSN 1550-6606

Gilleron, M.; Quesniaux, V. \& Puzo, G. (2003). Acylation state of the phosphatidylinositol hexamannosides from Mycobacterium bovis bacillus Calmette Guérin and Mycobacterium tuberculosis $\mathrm{H} 37 \mathrm{Rv}$ and its implication in Toll-like receptor response. The Journal of biological chemistry, Vol.278, No.32, (August 2003), pp. 29880-29889, ISSN 1083-351X

Gordon, S. (2003).Alternative activation of macrophages. Nature reviews. Immunology, Vol.3, No.1, (January 2003), pp. 23-35, ISSN 1474-1741

Greco, E.; Santucci, M.; Sali, M.; De Angelis, F.; Papi, M.; De Spirito, M.; Delogu, G.; Colizzi, V. \& Fraziano, M. (2010). Natural lysophospholipids reduce Mycobacterium tuberculosis-induced cytotoxicity and induce anti-mycobacterial activity by a phagolysosome maturation-dependent mechanism in A549 type II alveolar epithelial cells. Immunology, Vol.129, No.1, (January 2010), pp. 125-32, ISSN 13652567 
Gribar, S.; Richardson, W.; Sodhi, C. \& Hackam, D. (2008). No longer an innocent bystander: epithelial toll-like receptor signaling in the development of mucosal inflammation. Molecular medicine, Vol.14, No.9-10, (September- October 2008), pp. 645-659, ISSN 1528-3658

Hawkes, M.; Li, X.; Crockett, M.; Diassiti, A.; Finney, C.; Min-Oo, G.; Liles, W.; Liu, J. \& Kain, K. (2010). CD36 deficiency attenuates experimental mycobacterial infection. BMC infectious diseases, Vol.10, No.299, (October 2010), ISSN 1471-2334

Hawn, T.; Misch, E.; Dunstan, S.; Thwaites, G.; Lan, N.; Quy H.; Chau, T.; Rodrigues, S.; Nachman, A.; Janer, M.; Hien, T.; Farrar, J. \& Aderem, A. (2007). A common human TLR1 polymorphism regulates the innate immune response to lipopeptides. European journal of immunology, Vol.37, No.8, (August 2007), pp. 2280-2289, ISSN 1521-4141

Hernández-Pando, R.; Jeyanathan, M.; Mengistu, G.; Aguilar, D.; Orozco, H.; Harboe, M.; Rook, G. \& Bjune, G. (2000). Persistence of DNA from Mycobacterium tuberculosis in superficially normal lung tissue during latent infection. Lance, Vol.356, No.9248, (December 2000), pp. 2133-2138, ISSN 1474-547X

Herre, J.; Gordon, S. \& Brown, G. (2004a). Dectin-1 and its role in the recognition of betaglucans by macrophages. Molecular immunology, Vol.40, No.12, (February 2004), pp. 869-876, ISSN 1872-9142

Herre, J.; Marshall, A.; Caron, E.; Edwards, A.; Williams, D.; Schweighoffer, E.; Tybulewicz, V.; Reis e Sousa, C.; Gordon, S. \& Brown, G. (2004b). Dectin-1 uses novel mechanisms for yeast phagocytosis in macrophages. Blood, Vol.104, No.13, (December 2004), pp. 4038-4045, ISSN 1528-0020

Herrmann, J. \& Lagrange P. (2005). Dendritic cells and Mycobacterium tuberculosis: which is the Trojan horse?. Pathologie-biologie, Vol.53 , No.1, (February 2005), pp. 35-40, ISSN 1768-3114

Hetland, G. \& Wike, H. (1994). Antigen 85C of Mycobacterium bovis, BCG and M. tuberculosis promotes monocyte-CR3-mediated uptake of microbeads coated with mycobacterial products. Immunology, Vol.82, No.3, (July 1994), pp. 445-449, ISSN 1365-2567

Hoebe, K.; Georgel, P.; Rutschmann, S.; Du, X.; Mudd, S.; Crozat, K.; Sovath, S.; Shamel, L.; Hartung, T.; Zahringer, U. \& Beutler, B. (2005). CD36 is a sensor of diacylglycerides. Nature, Vol.433, No.7025, (February 2005), pp. 523-527, ISSN 14764687

Hölscher, C.; Reiling, N.; Schaible, U.; Hölscher, A.; Bathmann, C.; Korbel, D.; Lenz, I.; Sonntag, T.; Kröger, S.; Akira, S.; Mossmann, H.; Kirschning, C.; Wagner, H.; Freudenberg, M. \& Ehlers, S. (2008). Containment of aerogenic Mycobacterium tuberculosis infection in mice does not require MyD88 adaptor function for TLR2, 4 and -9. European journal of immunology, Vol.38, No.3, (March 2008), pp. 680-694, ISSN 1521-4141

Hoppe, H.; de Wet, B.; Cywes, C.; Daffé, M. \& Ehlers, M. (1997). Identification of phosphatidylinositol mannoside as a mycobacterial adhesin mediating both direct and opsonic binding to nonphagocytic mammalian cells. Infection and immunity, Vol.65, No.9, (September 1997), pp. 3896-3905, ISSN 1098-5522 
Ishikawa, E.; Ishikawa, T.; Morita, Y.; Toyonaga, K.; Yamada, H.; Takeuchi, O.; Kinoshita, T.; Akira, S.; Yoshikai, Y. \& Yamasaki S. (2009). Direct recognition of the mycobacterial glycolipid, trehalose dimycolate, by C-type lectin Mincle. The Journal of experimental medicine, Vol. 206, No.13, (December, 2009), pp. 2879-2888, ISSN 1540-9538

Jo, E. (2008). Mycobacterial interaction with innate receptors: TLRs, C-type lectins, and NLRs. Current opinion in infectious diseases, Vol. 21, No.3, (June 2008), pp. 279-86, ISSN 1535-3877

Jo, E.; Yang, C.; Choi, C. \& Harding, C. (2007) Intracellular signalling cascades regulating innate immune responses to Mycobacteria: branching out from Toll-like receptors. Cellular microbiology, Vol.9, No.5, (May 2007), pp. 1087-1098, ISSN 1462-5822

Kang, P.; Azad, A.; Torrelles, J.; Kaufman, T.; Beharka, A.; Tibesar, E.; DesJardin, L. \& Schlesinger L. (2005). The human macrophage mannose receptor directs Mycobacterium tuberculosis lipoarabinomannan-mediated phagosome biogenesis. The Journal of experimental medicine, Vol.202, No.7, (October 2005), pp. 987-999, ISSN 1540-9538

Kerr, M. \& Teasdale, R. (2009). Defining macropinocytosis. Traffic, Vol.10, No.4, (April 2009), pp. 364-371, ISSN 1600-0854

Kolářová, H.; Binó, L.; Pejchalová, K. \& Kubala, L. (2010). The expression of NADPH oxidases and production of reactive oxygen species by human lung adenocarcinoma epithelial cell line A549. Folia biologica, Vol.56, No.5, (August 2010), pp. 211-217, ISSN 0015-5500

Krause, K. (2004). Tissue distribution and putative physiological function of NOX family NADPH oxidases. Japanese journal of infectious diseases, Vol.57, No.5, (October 2004), pp. S28-S29, ISSN 1344-6304

Kwon, O.; Kim, J.; Kim, H.; Suh, G.; Park, J.; Chung, M.; Kim, H. \& Rhee C. (1998). Nitric oxide expression in airway epithelial cells in response to tubercle bacilli stimulation. Respirology, Vol.3, No.2, (June 1998), pp. 119-124, ISSN 1440-1843.

Kwon, S. \& George, S. (1999). Synergistic cytokine-induced nitric oxide production in human alveolar epithelial cells. Nitric Oxide, Vol.3, No.4, (August 1999), pp. 348357, ISSN 1089-8611

Lee, H.; Yuk, J.; Shin, D. \& Jo, E. (2009) Dectin-1 is inducible and plays an essential role for mycobacteria-induced innate immune responses in airway epithelial cells. Journal of clinical immunology, Vol.29, No.6, (November 2009), pp. 795-805, ISSN 1573-2592

Lemassu, A. \& Daffe, M. (1994). Structural features of the exocellular polysaccharides of Mycobacterium tuberculosis. The Biochemical journal, Vol.297, No.Pt2 , (January 1994), pp. 351-357, ISSN 1470-8728

Lin, Y.; Zhang, M. \& Barnes, P. (1998). Chemokine production by a human alveolar epithelial cell line in response to Mycobacterium tuberculosis. Infection and immunity, Vol.66, No.3, (March 1998), pp. 1121-1126, ISSN 1098-5522

Mapother, M. \& Songer, J. (1984). In vitro interaction of Mycobacterium avium with intestinal epithelial cells. Infection and immunity, Vol.45, No.1, (July 1984), pp. 67-73, ISSN 1098-5522

Matsumoto, M.; Tanaka, T.; Kaisho, T.; Sanjo, H.; Copeland, N.; Gilbert, D.; Jenkins, N. \& Akira, S. (1999). A novel LPS-inducible C-type lectin is a transcriptional target of 
NF-IL6 in macrophages. The Journal of immunology, Vol.163, No.9, (November 1999), pp. 5039-5048, ISSN 1550-6606

McGreal, E.; Miller, J. \& Gordon, S. (2005). Ligand recognition by antigen-presenting cell Ctype lectin receptors. Current opinion in immunology, Vol.17, No.1, (February 2005), pp. 18-24, ISSN 1879-0372

Means, T.; Jones, B.; Schromm, A.; Shurtleff, B.; Smith, J.; Keane, J.; Golenbock, D.; Vogel, S. \& Fenton, M. (2001). Differential effects of a Toll-like receptor antagonist on Mycobacterium tuberculosis induced macrophage responses. The Journal of immunology, Vol.166, No.6, (March 2001), pp. 4074-4082, ISSN 1550-6606

Meena, L. \& Rajni. (2010). Survival mechanisms of pathogenic Mycobacterium tuberculosis H37Rv. The FEBS journal, Vol.277, No.11, (June 2010), pp. 2416-2427, ISSN 17424658

Mehta, P.; Karls, R.; White, E.; Ades, E. \& Quinn, F. (2006). Entry and intracellular replication of Mycobacterium tuberculosis in cultured human microvascular endothelial cells. Microbial pathogenesis, Vol.41, No.2-3, (August-Septeember 2006), pp. 119-124, ISSN 1096-1208

Menozzi, F.; Reddy, V.; Cayet, D.; Raze, D.; Debrie, A.; Dehouck, M.; Cecchelli, R. \& Locht, C. (2006). Mycobacterium tuberculosis heparin-binding haemagglutinin adhesin (HBHA) triggers receptor-mediated transcytosis without altering the integrity of tight junctions. Microbes and infection, Vol.8, No.1, (January 2006), pp. 1-9, ISSN 1769-714X

Menozzi, F.; Rouse, J.; Alavi, M.; Laude-Sharp, M.; Muller, J.; Bischoff, R.; Brennan, M. \& Locht, C. (1996). Identification of a heparin-binding hemagglutinin present in mycobacteria. The Journal of experimental medicine, Vol.184, No.3, (September 1996), pp. 993-1001, ISSN 1540-9538

Mitchell, D.; Fadden, A. \& Drickamer, K. (2001). A novel mechanism of carbohydrate recognition by the C-type lectins DC-SIGN and DC-SIGNR. Subunit organization and binding to multivalent ligands. The Journal of biological chemistry, Vol.276, No.31, (August 2001), pp. 28939-2845, ISSN 1083-351X

Murphy, J.; Tedbury, P.; Homer-Vanniasinkam, S.; Walker, J. \& Ponnambalam, S. (2005). Biochemistry and cell biology of mammalian scavenger receptors. Atherosclerosis, Vol.182, No.1, (September 2005), pp. 1-15, ISSN 1879-1484

Neyrolles, O.; Hernández-Pando, R.; Pietri-Rouxel, F.; Fornès, P.; Tailleux, L.; Barrios Payán, J.; Pivert, E.; Bordat, Y.; Aguilar, D.; Prévost, M.; Petit, C. \& Gicquel, B. (2006). Is adipose tissue a place for Mycobacterium tuberculosis persistence? PLoS one, Vol.1, No.1, (December 2006), pp. e43, ISSN 1932-6203

Nigou, J.; Zelle-Rieser, C.; Gilleron, M.; Thurnher, M. \& Puzo, G. (2001). Mannosylated lipoarabinomannans inhibit IL-12 production by human dendritic cells: evidence for a negative signal delivered through the mannose receptor. The Journal of immunology, Vol.166, No.12, (June 2001), pp. 7477-7485, ISSN 1550-6606

Noss, E.; Pai, R.; Sellati, T.; Radolf, J.; Belisle, J.; Golenbock, D.; Boom, W. \& Harding, C. (2001).Toll-like receptor 2-dependent inhibition of macrophage class II MHC expression and antigen processing by $19-\mathrm{kDa}$ lipoprotein of Mycobacterium tuberculosis. The Journal of immunology, Vol.167, No.2, (July 2001), pp. 910-918, ISSN 1550-6606 
Ocampo, M.; Rodríguez, D.; Curtidor, H.; Vanegas, M.; Patarroyo, M.A. \& Patarroyo, M.E. (2011). Peptides derived from Mycobacterium tuberculosis Rv2301 protein are involved in invasion to human epithelial cells and macrophages. Amino Acids, (May 2011), ISSN, 1438-2199

Opitz, B.; Eitel, J.; Meixenberger, K. \& Suttorp, N. (2009). Role of Toll-like receptors, NODlike receptors and RIG-I-like receptors in endothelial cells and systemic infections. Thrombosis and haemostasis, Vol.102, No.6, (December 2009), pp. 1103-1109, ISSN 1438-2199

Ozeki, Y.; Tsutsui, H.; Kawada, N.; Suzuki, H.; Kataoka, M.; Kodama, T.; Yano, I.; Kaneda, K. \& Kobayashi K. (2006). Macrophage scavenger receptor down-regulates mycobacterial cord factor-induced proinflammatory cytokine production by alveolar and hepatic macrophages. Microbial pathogenesis, Vol.40, No.4, (April 2006), pp. 171-176, ISSN 1096-1208

Palecanda, A. \& Kobzik, L. (2001). Receptors for unopsonized particles: the role of alveolar macrophage scavenger receptors. Current molecular medicine, Vol.1, No.5, (November 2001), pp. 589-595, ISSN 1875-5666

Palecanda, A.; Paulauskis, J.; Al-Mutairi, E.; Imrich, A.; Qin, G.; Suzuki, H.; Kodama, T.; Tryggvason, K.; Koziel, H. \& Kobzik L. (1999). Role of the scavenger receptor MARCO in alveolar macrophage binding of unopsonized environmental particles. The Journal of experimental medicine, Vol.189, No.9, (May 1999), pp. 1497-1506, ISSN 1540-9538

Patel, J. \& Galán, J. (2006). Differential activation and function of Rho GTPases during Salmonella-host cell interactions. The Journal of cell biology, Vol.175, No.3, (November 2006), pp. 453-463, ISSN 1540-8140

Pearson, A. (1996). Scavenger receptors in innate immunity. Current opinion in immunology, Vol.8, No.1, (February, 1996), pp. 20-28, ISSN 1879-0372

Pecora, N.; Gehring, A.; Canaday, D.; Boom, W; \& Harding, C. (2006). Mycobacterium tuberculosis LprA is a lipoprotein agonist of TLR2 that regulates innate immunity and APC function. The Journal of immunology, Vol.177, No.1, (July 2006), pp. 422429, ISSN 1550-6606

Pethe, K.; Alonso, S.; Biet, F.; Delogu, G.; Brennan, M.; Locht, C. \& Menozzi F. (2001). The heparin-binding haemagglutinin of $\mathrm{M}$. tuberculosis is required for extrapulmonary dissemination. Nature. Vol.412, No.6843, (July 2001), pp. 190-194, ISSN 1476-4687

Pitarque, S.; Herrmann, J.; Duteyrat, J.; Jackson, M.; Stewart, G.; Lecointe, F.; Payre B, Schwartz O, Young DB, Marchal G, Lagrange PH, Puzo G, Gicquel B, Nigou, J. \& Neyrolles, O. (2005). Deciphering the molecular bases of Mycobacterium tuberculosis binding to the lectin DC-SIGN reveals an underestimated complexity. The Biochemical journal, Vol.392, No.3, (December 2005), pp. 615-624, ISSN1470-8728

Rastogi, N.; Labrousse, V. \& de Sousa, J. (1992). Mycobacterial growth and ultrastructure in mouse L-929 fibroblasts and bone marrow-derived macrophages: evidence that infected fibroblasts secrete mediators capable of modulating bacterial growth in macrophages. Current microbiology, Vol.25, No.4, (October 1992), pp. 203-213, ISSN 1432-0991 
Reddy, V. \& Hayworth, D. (2002). Interaction of Mycobacterium tuberculosis with human respiratory epithelial cells (HEp-2). Tuberculosis, Vol.82, No.1, (February 2002), pp. 31-36, ISSN 1873-281X

Reddy, V. \& Kumar B. (2000). Interaction of Mycobacterium avium complex with human respiratory epithelial cells. The Journal of infectious diseases, Vol.181, No.3, (March 2000), pp. 1189-1193, ISSN 1537-6613

Reiling, N.; Hölscher, C.; Fehrenbach, A.; Kröger, S.; Kirschning, C.; Goyert. S. \& Ehlers, S. (2002). Cutting edge: Toll-like receptor (TLR)2- and TLR4-mediated pathogen recognition in resistance to airborne infection with Mycobacterium tuberculosis. The Journal of immunology, Vol.169, No.7, (October 2002), pp. 3480-3484, ISSN 15506606

Rivas-Santiago, B.; Hernandez-Pando, R.; Carranza, C.; Juarez, E.; Contreras, J, AguilarLeon, D.; Torres, M. \& Sada E. (2008). Expression of cathelicidin LL-37 during Mycobacterium tuberculosis infection in human alveolar macrophages, monocytes, neutrophils, and epithelial cells. Infection and immunity, Vol.76, No.3, (March 2008) pp. 935-941, ISSN 1098-5522

Rivas-Santiago, B.; Sada, E.; Tsutsumi, V.; Aguilar-Leon, D.; Contreras, J. \& HernandezPando, R. (2006). beta-Defensin gene expression during the course of experimental tuberculosis infection. The Journal of infectious diseases, Vol.194, No.5, (September 2006), pp. 697-701, ISSN 1537-6613

Rivas-Santiago, B.; Schwander, S.; Sarabia, C.; Diamond, G., Klein-Patel, M.; HernandezPando, R.; Ellner, J. \& Sada, E. (2005). Human \{beta\}-defensin 2 is expressed and associated with Mycobacterium tuberculosis during infection of human alveolar epithelial cells. Infection and immunity, Vol.73, No.8, (August 2005), pp. 4505-4511, ISSN 1098-5522

Roach, D.; Bean, A.; Demangel, C.; France, M.; Briscoe, H. \& Britton, W. (2002). TNF regulates chemokine induction essential for cell recruitment, granuloma formation, and clearance of mycobacterial infection. The Journal of immunology, Vol.168, No.9, (May 2002), pp. 4620-4627, ISSN 1550-6606

Rooyakkers, A. \& Stokes R. (2005). Absence of complement receptor 3 results in reduced binding and ingestion of Mycobacterium tuberculosis but has no significant effect on the induction of reactive oxygen and nitrogen intermediates or on the survival of the bacteria in resident and interferon-gamma activated macrophages. Microbial pathogenesis, Vol.39, No.3, (September 2005), pp. 57-67, ISSN 1096-1208

Rothfuchs, A.; Bafica, A.; Feng, C.; Egen, J.; Williams, D.; Brown, G.\& Sher, A. (2007). Dectin1 interaction with Mycobacterium tuberculosis leads to enhanced IL-12p40 production by splenic dendritic cells. The Journal of immunology, Vol.179, No.6, (September 2007), pp. 3463-3471, ISSN 1550-6606

Roy, S.; Sharma, S.; Sharma, M.; Aggarwal, R. \& Bose, M. (2004). Induction of nitric oxide release from the human alveolar epithelial cell line A549: an in vitro correlate of innate immune response to Mycobacterium tuberculosis. Immunology, Vol. 112, No.3, (July 2004), pp. 471-80, ISSN 1365-2567

Ryffel, B.; Fremond, C.; Jacobs, M.; Parida, S.; Botha, T.; Schnyder, B. \& Quesniaux, V. (2005). Innate immunity to mycobacterial infection in mice: critical role for toll-like 
receptors. Tuberculosis, Vol.85, No.5-6, (September-November 2005) pp. 395-405, ISSN 1873-281X

Saiga, H.; Shimada, Y. \& Takeda K. (2011). Innate immune effectors in mycobacterial infection. Clinical \& developmental immunology, Vol.2011, No.347594, (January 2011), pp. 1-8, ISSN 1740-2530

Saini, N.; Sharma, M.; Chandolia, A.; Pasricha, R.; Brahmachari, V. \& Bose M. (2008). Characterization of Mce4A protein of Mycobacterium tuberculosis: role in invasion and survival. BMC microbiology, Vol.8, No.200, (November 2008), ISSN 1471-2180

Schäfer, G.; Jacobs, M.; Wilkinson, R. \& Brown, G. (2009). Non-opsonic recognition of Mycobacterium tuberculosis by phagocytes. Journal of innate immunity, Vol.1, No.3, (April 2009), pp. 231-243, ISSN 1662-8128

Schlesinger, L. (1993). Macrophage phagocytosis of virulent but not attenuated strains of Mycobacterium tuberculosis is mediated by mannose receptors in addition to complement receptors. The Journal of immunology, Vol.150, No.7, (April 1993), pp. 2920-2930, ISSN 1550-6606

Schlesinger, L.; Hull, S. \& Kaufman, T. (1994). Binding of the terminal mannosyl units of lipoarabinomannan from a virulent strain of Mycobacterium tuberculosis to human macrophages. The Journal of immunology, Vol.152, No.8, (April 1994), pp. 4070-4079, ISSN 1550-6606

Schneberger, D.; Aharonson-Raz, K. \& Singh, B. (2011). Monocyte and macrophage heterogeneity and Toll-like receptors in the lung. Cell and tissue research, Vol.343, No.1, (January 2011), pp. 97-106, ISSN 1432-0878

Sharma, M.; Sharma, S.; Roy, S.; Varma, S. \& Bose, M. (2007). Pulmonary epithelial cells are a source of interferon-gamma in response to Mycobacterium tuberculosis infection. Immunol Cell Biol, Vol.85, No.3, (April-May 2007), pp. 229-237, ISSN 1440-1711

Shepard, C. (1955). Phagocytosis by HeLa cells and their susceptibility to infection by human tubercle bacilli. Proceedings of the Society for Experimental Biology and Medicine, Vol.90, No.2, (November 1955), pp. 392-396, ISSN 1525-1373

Shin, D.; Yang, C.; Yuk, J.; Lee, J.; Kim, K.; Shin, S.; Takahara, K.; Lee, S. \& Jo, E. (2008). Mycobacterium abscessus activates the macrophage innate immune response via a physical and functional interaction between TLR2 and Dectin-1. Cellular microbiology, Vol.10, No.8, (August 2008), pp. 1608-1621, ISSN 1462-5822

Sidobre, S.; Nigou, J.; Puzo, G.; Rivière, M. (2000). Lipoglycans are putative ligands for the human pulmonary surfactant protein A attachment to mycobacteria. Critical role of the lipids for lectin-carbohydrate recognition. The Journal of biological chemistry, Vol.275, No.4, (January 2000), pp. 2415-2422, ISSN 1083-351X

Soilleux, E.; Morris, L.; Leslie, G.; Chehimi, J.; Luo, Q.; Levroney, E.; Trowsdale, J.; Montaner, L.; Doms, R.; Weissman, D.; Coleman, N. \& Lee, B. (2002). Constitutive and induced expression of DC-SIGN on dendritic cell and macrophage subpopulations in situ and in vitro. Journal of leukocyte biology, Vol.71, No.3, (March, 2002), pp. 445-457, ISSN 1938-3673

Sow, F.; Nandakumar, S.; Velu, V.; Kellar, K.; Schlesinger, L.; Amara, R.; Lafuse, W.; Shinnick, T. \& Sable, S. (2011). Mycobacterium tuberculosis components stimulate production of the antimicrobial peptide hepcidin. Tuberculosis, Vol.91, No.4, (July 2011) pp. 314-321, ISSN 1873-281X 
Srivastava, M.; Meinders, A.; Steinwede, K.; Maus, R.; Lucke, N.; Buhling, F.; Ehlers, S.; Welte, T. \& Maus U. (2007). Mediator responses of alveolar macrophages and kinetics of mononuclear phagocyte subset recruitment during acute primary and secondary mycobacterial infections in the lungs of mice. Cellular microbiology, Vol.9, No.3, (March, 2007) pp. 738-752, ISSN 1462-5822

Stahl, P. \& Ezekowitz, R. (1998). The mannose receptor is a pattern recognition receptor involved in host defense. Current opinion in immunology, Vol.10, No.1, (February 1998) pp. 50-55, ISSN 1879-0372

Stephenson, J. \& Shepherd, V. (1987). Purification of the human alveolar macrophage mannose receptor. Biochemical and biophysical research communications, Vol.148, No.2, (October 1987), pp. 883-889, ISSN 1090-2104

Stokes, R.; Thorson, L. \& Speert, D. (1998). Nonopsonic and opsonic association of Mycobacterium tuberculosis with resident alveolar macrophages is inefficient. The Journal of immunology, Vol.160, No.11, (June 1998), pp. 5514-5521, ISSN 15506606

Sugawara, I.; Yamada, H.; Li, C.; Mizuno, S.; Takeuchi. O. \& Akira, S. (2003). Mycobacterial infection in TLR2 and TLR6 knockout mice. Microbiology and immunology, Vol.47, No.5, (2003), 327-336, ISSN 1348-0421

Suzuki, T.; Chow, C. \& Downey, G. (2008). Role of innate immune cells and their products in lung immunopathology. The international journal of biochemistry $\mathcal{E}$ cell biology, Vol.40, No.6-7, (June- July 2008), pp. 1348-1361, ISSN 1878-5875

Swanson, J. \& Watts, C. (1995). Macropinocytosis. Trends in cell biology, Vol.5, No.11, (November 1995), pp. 424-428, ISSN 1879-3088

Swanson, J. (1989). Phorbol esters stimulate macropinocytosis and solute flow through macrophages. Journal of cell science, Vol.94, (September 1989), pp. 135-142, ISSN 1477-9137

Tailleux, L.; Pham-Thi, N.; Bergeron-Lafaurie, A.; Herrmann, J.; Charles, P.; Schwartz, O.; Scheinmann, P.; Lagrange, P.; de Blic, J.; Tazi, A.; Gicquel, B. \& Neyrolles, O. (2005). DC-SIGN induction in alveolar macrophages defines privileged target host cells for mycobacteria in patients with tuberculosis. PLoS medicine, Vol.2, No.12, (December 2005), pp. e381, ISSN 1549-1676

Tailleux, L.; Schwartz, O.; Herrmann, J.; Pivert, E.; Jackson, M.; Amara, A.; Legres, L.; Dreher, D.; Nicod, L.; Gluckman, J.; Lagrange, P,; Gicquel, B. \& Neyrolles, O. (2003). DC-SIGN is the major Mycobacterium tuberculosis receptor on human dendritic cells. The Journal of experimental medicine, Vol.197, No.1, (January 2003), pp. 121-127, ISSN 1540-9538

Takabayshi, K.; Corr, M.; Hayashi, T.; Redecke, V.; Beck, L.; Guiney, D.; Sheppard, D. \& Raz, E. (2006). Induction of a homeostatic circuit in lung tissue by microbial compounds. Immunity, Vol.24, No.4, (April 2006), pp. 475-487, ISSN 1097-4180

Takeda, K.\& Akira, S. (2005). Toll-like receptors in innate immunity. International immunology, Vol.17, No.1, (January 2005), pp. 1-14, ISSN 1460-2377

Taylor, P.; Brown, G.; Reid, D.; Willment, J.; Martinez-Pomares, L.; Gordon, S. \& Wong, S. (2002). The beta-glucan receptor, Dectin-1, is predominantly expressed on the surface of cells of the monocyte/macrophage and neutrophil lineages. The Journal of immunology, Vol.169, No.7, (October 2002), pp. 3876-3882, ISSN 1550-6606 
Taylor, P.; Tsoni, S.; Willment, J.; Dennehy, K.; Rosas, M.; Findon, H.; Haynes, K.; Steele, C.; Botto, M.; Gordon, S. \& Brown, G. (2007). Dectin-1 is required for beta-glucan recognition and control of fungal infection. Nature immunology, Vol.8, No.1, (January 2007), pp. 31-38, ISSN 1529-2916

Thorson, L.; Doxsee, D.; Scott, M.; Wheeler, P. \& Stokes, R. (2001). Effect of mycobacterial phospholipids on interaction of Mycobacterium tuberculosis with macrophages. Infection and immunity. Vol.69, No.4, (April 2001), pp. 2172-2179, ISSN 1098-5522

Tjärnlund, A.; Guirado, E.; Julián, E.; Cardona, P. \& Fernández, C. (2006). Determinant role for Toll-like receptor signalling in acute mycobacterial infection in the respiratory tract. Microbes and infection, Vol.8, No.7, (June 2006), pp. 1790-1800, ISSN 1769-714X

Torrelles, J.; Azad, A. \& Schlesinger, L. (2006). Fine discrimination in the recognition of individual species of phosphatidyl-myo-inositol mannosides from Mycobacterium tuberculosis by C-type lectin pattern recognition receptors. The Journal of immunology, Vol.177, No.3, (August 2006), pp. 1805-1816, ISSN 1550-6606

Torrelles, J.; Azad, A.; Henning, L.; Carlson, T. \& Schlesinger, L. (2008). Role of C-type lectins in mycobacterial infections. Current drug targets, Vol.9, No.2, (February, 2008) pp. 102-112, ISSN 1873-5592

Van Buul, J.; Fernandez-Borja, M.; Anthony, E. \& Hordijk, P. (2005). Expression and localization of NOX2 and NOX4 in primary human endothelial cells. Antioxid $\mathcal{E}$ Redox Signal, Vol.7, No.3-4, (March-April 2005), pp. 308-317, ISSN 1557-7716

van de Veerdonk, F.; Teirlinck, A.; Kleinnijenhuis, J.; Kullberg, B.; van Crevel, R.; van der Meer, J.; Joosten, L. \& Netea M. (2010). Mycobacterium tuberculosis induces IL-17A responses through TLR4 and Dectin-1 and is critically dependent on endogenous IL-1. Journal of leukocyte biology, Vol.88, No.2, (August, 2010), pp. 227-232, ISSN 1938-3673

Velasco-Velázquez, M.; Barrera, D.; González-Arenas, A.; Rosales, C. \& Agramonte-Hevia, J. (2003) Macrophage-Mycobacterium tuberculosis interactions: role of complement receptor 3. Microbial pathogenesis, Vol.35, No.3, (September 2003), pp. 125-131, ISSN 1096-1208

Verbelen, C.; Dupres, V.; Raze, D.; Bompard, C.; Locht, C. \& Dufrêne Y. (2008). Interaction of the mycobacterial heparin-binding hemagglutinin with actin, as evidenced by single-molecule force spectroscopy. Journal of bacteriology, Vol.193, No.23, (December 2008), pp. 7614-7620, ISSN 1098-5530

Vignal, C.; Guerardel, Y.; Kremer, L.; Masson, M.; Legrand, D.; Mazurier, J. \& Elass, E. (2003). Lipomannans, but not lipoarabinomannans, purified from Mycobacterium chelonae and Mycobacterium kansasii induce TNF-alpha and IL-8 secretion by a CD14-Toll-like receptor-2 -dependent mechanism. The Journal of immunology, Vol.171, No.4, (August 2003), pp. 2014-2023, ISSN 1550-6606

West, A.; Brodsky, I.; Rahner, C.; Woo, D.; Erdjument-Bromage, H.; Tempst, P.; Walsh, M.; Choi, Y.; Shadel, G. \& Ghosh, S. (2011). TLR signalling augments macrophage bactericidal activity through mitochondrial ROS. Nature, Vol.472, No.7344 (April 2011), pp.476-80, ISSN 1476-4687

Willment, J.; Lin, H.; Reid, D.; Taylor, P.; Williams, D.; Wong, S.; Gordon, S.\& Brown, G. (2003). Dectin-1 expression and function is enhanced on alternatively activated and 
GMCSF treated macrophages and negatively regulated by IL-10, dexamethasone and LPS. The Journal of immunology, Vol.171, No.9, (November 2003), pp. 4569-4573, ISSN 1550-6606

World Health Organization. Global tuberculosis control report 2010. http://www.who.int/tb/publications/global_report/2010/en/index.html

Yadav, M. \& Schorey, J. (2006). The beta-glucan receptor Dectin-1 functions together with TLR2 to mediate macrophage activation by mycobacteria. Blood, Vol.108, No.8, (November 2006), pp. 3168-3175, ISSN 1528-0020

Yang, C.; Shin, D.; Kim, K.; Lee, Z.; Lee, C.; Park, S.; Bae, Y. \& Jo E. (2009). NADPH oxidase 2 interaction with TLR2 is required for efficient innate immune responses to mycobacteria via cathelicidin expression. The Journal of immunology. Vol.182, No.6, (March 2009), pp. 3696-3705, ISSN 1550-6606 


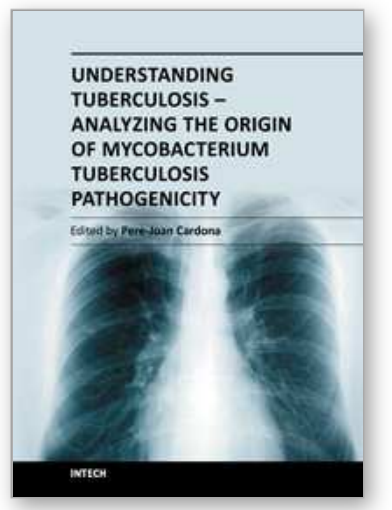

\section{Understanding Tuberculosis - Analyzing the Origin of Mycobacterium Tuberculosis Pathogenicity \\ Edited by Dr. Pere-Joan Cardona}

ISBN 978-953-307-942-4

Hard cover, 560 pages

Publisher InTech

Published online 24, February, 2012

Published in print edition February, 2012

Mycobacterium tuberculosis in an attempt to understand the extent to which the bacilli has adapted itself to the host and to its final target. On the other hand, there is a section in which other specialists discuss how to manipulate this immune response to obtain innovative prophylactic and therapeutic approaches to truncate the intimal co-evolution between Mycobacterium tuberculosis and the Homo sapiens.

\section{How to reference}

In order to correctly reference this scholarly work, feel free to copy and paste the following:

B.E. Garcia-Perez, N.S. Castrejon-Jimenez and J. Luna-Herrera (2012). The Role of Non-Phagocytic Cells in Mycobacterial Infections, Understanding Tuberculosis - Analyzing the Origin of Mycobacterium Tuberculosis Pathogenicity, Dr. Pere-Joan Cardona (Ed.), ISBN: 978-953-307-942-4, InTech, Available from: http://www.intechopen.com/books/understanding-tuberculosis-analyzing-the-origin-of-mycobacteriumtuberculosis-pathogenicity/the-role-of-non-phagocytic-cells-in-mycobacterial-infections

\section{INTECH}

open science | open minds

\section{InTech Europe}

University Campus STeP Ri

Slavka Krautzeka 83/A

51000 Rijeka, Croatia

Phone: +385 (51) 770447

Fax: +385 (51) 686166

www.intechopen.com

\section{InTech China}

Unit 405, Office Block, Hotel Equatorial Shanghai

No.65, Yan An Road (West), Shanghai, 200040, China

中国上海市延安西路65号上海国际贵都大饭店办公楼 405 单元

Phone: +86-21-62489820

Fax: $+86-21-62489821$ 
(C) 2012 The Author(s). Licensee IntechOpen. This is an open access article distributed under the terms of the Creative Commons Attribution 3.0 License, which permits unrestricted use, distribution, and reproduction in any medium, provided the original work is properly cited. 